\title{
Determinanty struktury kapitałowej w teoriach substytucji
}

\begin{abstract}
Marek Barowicz*
Celem artykutu jest identyfikacja oraz ocena sity i kierunku wptywu wybranych determinant na strukturę kapitatowa przedsiębiorstw notowanych na Giełdzie Papierów Wartościowych $w$ Warszawie w ramach teorii substytucji. Artykut ma charakter teoretyczno-empiryczny. Część teoretyczna obejmuje charakterystykę determinant struktury kapitatowej występujacych $w$ teoriach substytucji. Czesść empiryczna dotyczy weryfikacji hipotez $w$ zakresie wptywu różnych czynników na strukturę kapitatowa przedsiębiorstwa $w$ ramach teorii substytucji (tj. teorii uwzględniajacej koszty bankructwa oraz teorii uwzględniającej koszty agencji).
\end{abstract}

Slowa kluczowe: kapitał, struktura kapitałowa, determinanty, struktury kapitałowej, teorie struktury kapitałowej

Nadesłany: 07.09.2012 | Zaakceptowany do druku: 10.12.2012

\section{Determinants of corporate capital structure in the trade-off theories}

The goal of this article is identification and estimation of the influence of chosen determinants on corporate capital structure according to the trade-off theories (i.e. bankruptcy cost theory and agency cost theory).

The article consists of two parts: theoretical and empirical one. Theoretical part contains description of the capital structure determinants appearing in the trade-off theories. Empirical part relates to the verification of hypothesis within the range of the influence of the determinants on corporate capital structure.

Keywords: capital, capital structure, determinants of corporate capital structure, capital structure theories

Submitted: 07.09.2012 | Accepted: 10.12.2012

JEL: C02, C10, G32 


\section{Wprowadzenie}

Przedsiębiorstwa dążą do osiągnięcia optymalnej, a więc najkorzystniejszej w danych warunkach, struktury kapitałowej. Od niej zależy bowiem efektywność szeregu decyzji operacyjnych i inwestycyjnych, które oddziałują na zyski przedsiębiorstwa.

Dobór źródeł finansowania przedsiębiorstwa, a tym samym jego rynkowa wartość, zdeterminowane są jednak różnymi czynnikami o charakterze ilościowym i jakościowym, a także mikro- i makroekonomicznym. Maksymalizacja wartości dla właścicieli stanowi konsekwencję pozyskania odpowiednich źródeł finansowania i nadania im formy właściwej w danych warunkach struktury kapitału.

Czynniki kształtujące strukturę kapitałową są w wysokim stopniu zróżnicowane co do swej istoty. Zróżnicowanie to wynika $\mathrm{z}$ trudności z identyfikacją determinant tej struktury, wieloaspektowością ich wpływu, pomiarem sity i kierunku wpływu na strukturę kapitałową. Ponadto czynniki te oddziałują w określonych warunkach prawno-ekonomicznych. Dodatkowa trudność wynika ze wzajemnego oddziaływania między sobą różnych czynników ilościowo-jakościowych oraz właściwego doboru formul szacowania ich wpływu na strukturę kapitałową, uwzględniającego cechy tych czynników, niekiedy całkowicie od siebie odmienne. W przypadku uwzględniania więcej niż dwóch czynników może bowiem zaistnieć tzw. efekt interakcji, polegający na zmianie wartości danego czynnika w zależności od zmiany innych determinant.

Instrumentem pomocnym w poznaniu i właściwym szacowaniu determinant są teorie struktury kapitału. Ich implementacja w praktyce gospodarczej często stwarza jednak konieczność dokonywania korekt uwzględniających warunki gospodarki polskiej, zapewniających porównywalność mierników i procedur obliczeniowych.

Celem niniejszego artykułu jest przedstawienie oraz ocena oddziaływania różnych czynników na strukturę kapitałową w ramach teorii substytucji.

\section{Charakterystyka kosztów bankructwa}

Korzystanie przez przedsiębiorstwo z kapitałów obcych implikuje zarówno korzyści w formie odsetkowych tarcz podat- kowych, jak i koszty pod postacią kosztów bankructwa oraz kosztów agencji.

Koszty bankructwa powstają, gdy przedsiębiorstwo nie jest w stanie regulować swoich zobowiązań wobec wierzycieli (Haugen i Senbet, 1978, s. 384). Związane są one z powstaniem dodatkowych wydatków w spółce, powodujących wzrost średniego kosztu kapitału i spadek rynkowych cen jej akcji (Jerzemowska, 1999, s. 100). Koszty bankructwa można podzielić na bezpośrednie i pośrednie (Ross, Westerfield i Jordan 1993, s. 534-535).

Do bezpośrednich kosztów bankructwa zalicza się prawne, księgowe i administracyjne opłaty bezpośrednio związane $\mathrm{z}$ bankructwem (Haugen i Senbet 1978, s. 385). Bezpośrednie koszty bankructwa są sygnatem dla przedsiębiorstwa do wstrzymania się od finansowania długiem. Według Warnera $(1977$, s. 337) relacja bezpośrednich kosztów bankructwa do rynkowej wartości przedsiębiorstwa ulega redukcji wraz ze wzrostem tej wartości.

Pośrednie koszty bankructwa stanowią koszty unikania zagrożenia bankructwem wskutek wystąpienia trudności finansowych $\mathrm{w}$ przedsiębiorstwie (pogorszenia wyników działalności, niewypłacalności). Do pośrednich kosztów bankructwa zalicza się koszty umów wynikających ze zmienności polityki inwestycyjnej przedsiębiorstwa i decyzji w zakresie alokacji jego zasobów (Jerzemowska, 1999, s. 101). Pośrednie koszty bankructwa wynikają ze zmniejszenia popytu na produkty przedsiębiorstwa z uwagi na obawy klientów związane $\mathrm{z}$ ich serwisem, wzrostu kosztów dostaw z uwagi na pogorszenie stosunków między przedsiębiorstwem a dostawcami, ucieczki kluczowych pracowników do innych przedsiębiorstw (Haugen i Senbet 1988, s. 31). Bezpośrednie i pośrednie koszty bankructwa zaliczane są do kosztów trudności finansowych pojawiających się, gdy przedsiębiorstwo nie dokonuje płatności w terminie.

Według Kima (1978, s. 47-48) wyróżnia się następujące skutki wystąpienia kosztów bankructwa:

- w zależności od tego, czy bankructwo przybierze postać likwidacji, czy reorganizacji, pojawia się sprzedaż aktywów jednostki poniżej ich rynkowej wartości lub koszty pośrednie bankructwa,

- pojawiaja się koszty administracyjne ponoszone na rzecz podmiotów związanych $\mathrm{z}$ przedsiębiorstwem i stron trze- 
cich (prawników, członków zarządu, księgowych, prowadzących licytację, sędziów, rzeczoznawców),

- pojawia się utrata tarcz i ulg podatkowych w związku z brakiem kontynuacji działalności.

Nadmierne zadłużenie stanowi zagrożenie dla przedsiębiorstwa w postaci bankructwa (Stiglitz, 1988, s. 124). Koszty bankructwa wpływają na wzrost średniego kosztu kapitału oraz obniżenie rynkowej wartości cen akcji spółki. Koszty bankructwa odzwierciedlają niedoskonałości rynku kapitałowego (Kraus i Litzenberger, 1973, s. 911).

Według teorii bankructwa przedsiębiorstwo nie powinno stosować nadmiernej dźwigni finansowej. Ryzyko finansowe związane $\mathrm{z}$ nadmierną dźwignią podwyższa koszt kapitału przedsiębiorstwa. Wysoki stopień dźwigni finansowej zwiększa prawdopodobieństwo wystąpienia bankructwa. Jeżeli poziom dźwigni jest niski, wzrost zadłużenia nie wpływa znacząco na wzrost prawdopodobieństwa bankructwa. Jeżeli natomiast udział długu w strukturze kapitałowej jest znaczny, każdorazowy wzrost dźwigni finansowej ma dużo większy wpływ na koszt kapitału. Stopa oprocentowania długu będzie wzrastać powoli w przypadku niskiego zadłużenia. Jeżeli jednak strukturę kapitałową zacznie cechować wyższe ryzyko finansowe, stopa procentowa zacznie szybko wzrastać (Baxter, 1967, s. 402).

W literaturze przedmiotu w zakresie kosztów trudności finansowych (kosztów bankructwa) można spotkać się z poglądem (Myers 1984, s. 580-581), że przedsiębiorstwa charakteryzujące się wysokim ryzykiem finansowym powinny ograniczać zadłużenie. Przedsiębiorstwa o niskim ryzyku finansowym powinny natomiast zwiększać zadłużenie do momentu, gdy oczekiwane koszty bankructwa skompensują korzyści podatkowe wynikające $\mathrm{z}$ zaciagania długu.

Koszty bankructwa są wyższe w przedsiębiorstwach mających duży udział w swych aktywach wartości niematerialnych i prawnych. Przedsiębiorstwa ustabilizowane na rynku, posiadające większy udział rzeczowych aktywów trwałych, a dzięki temu o niższych kosztach bankructwa, mogą zaciągać więcej długów w stosunku do podmiotów o wysokim poziomie kosztów badań i rozwoju. Według Oplera i Titmana (1994, s. 1015) przedsiębiorstwa korzysta- jące w dużym stopniu z kapitału obcego w celu finansowania badań i rozwoju szczególnie narażone są na koszty bankructwa w okresach niekorzystnej koniunktury gospodarczej. Znaczenie kosztów bankructwa maleje w przypadku przedsiębiorstw będących w fazie dojrzałości. Przekłada się to na wyższy poziom zadłużenia w przypadku dużych podmiotów (Frielinghaus, Mostert i Firer 2005, s. 12).

Na wystąpienie bankructwa duży wpływ wywierają inwestycje. Oddziałuja one na wzrost wartości aktywów, przez wielkość generowanych przez przedsiębiorstwo zysków w warunkach dobrej koniunktury gospodarczej. Inwestycje mogą prowadzić również do obniżenia wartości aktywów w ich funkcji zabezpieczającej w warunkach niekorzystnej koniunktury, gdy pożyczkobiorca ma trudności z regulowaniem swoich zobowiązań (Titman, Tompaidis i Tsyplakov 2004, s. 166). Według Maksimovica i Zechnera (1991, s. 1619) ryzyko związane $\mathrm{Z}$ realizowanym projektem inwestycyjnym jest wewnętrznie determinowane przez decyzje inwestycyjne podejmowane przez wszystkie przedsiębiorstwa w danej branży.

\section{Charakterystyka kosztów agencji}

W znacznej części literatury poświęconej strukturze kapitałowej doszukuje się jej determinant $\mathrm{w}$ różnicy interesów między różnymi grupami wywierającymi wpływ na dysponowanie aktywami przedsiębiorstwa, a zwłaszcza w kosztach wynikających z różnicy tych interesów, określanych mianem kosztów agencji (Mehran, 1992, s. 555; Gajdka, 2002, s. 188).

Koszty agencji związane sa z kosztami sporządzania, egzekwowania i kontroli umów między poszczególnymi grupami interesów w przedsiębiorstwie (akcjonariuszami, kierownictwem, pracownikami, wierzycielami, dostawcami, klientami). Koszty agencji można również określić jako dodatkowe koszty ponoszone wskutek powstania sytuacji konfliktowych między grupami zainteresowanymi funkcjonowaniem spółki (Jerzemowska, 1999, s. 110). Konflikt interesów występuje najczęściej między akcjonariuszami a kierownictwem przedsiębiorstwa oraz między akcjonariuszami (kierownictwem) a wierzycielami przedsiębiorstwa (Harris i Raviv 1991, s. 300-301).

Źródłem konfliktów między akcjonariuszami a kierownictwem jest oddzielenie 
własności od kontroli nad przedsiębiorstwem (Harvey, Lins i Roper 2004, s. 4). Kierownictwo dąży do wzrostu poziomu konsumpcji dzięki wyższym wynagrodzeniom, realizacji inwestycji o niższym ryzyku, a przez to niższej dźwigni finansowej (w celu ograniczenia prawdopodobieństwa wystapienia bankructwa podmiotu) oraz stabilizacji zatrudnienia. Celem akcjonariuszy są natomiast wyższe zyski, nawet kosztem wyższego ryzyka.

Konflikt interesów na płaszczyźnie kierownictwo (kluczowi pracownicy)-akcjonariusze redukuje się przez osiągnięcie właściwej kombinacji długu i kapitału własnego oraz zmiany w umowach głównie w zakresie wynagrodzenia (Chang, 1992, s. 1155). Aby związać kierownictwo z przedsiębiorstwem (i z interesem akcjonariuszy), stosuje się wynagrodzenie uzależnione od wyników osiąganych przez spółkę lub proponuje się menedżerom nabycie akcji spółki. Według Mehrana (1992, s. 539) tego typu konflikty niwelowane są przez zawieranie umów kompensacyjnych, inwestowanie przez kierownictwo w akcje spółki oraz kontrolę działań kierownictwa przez akcjonariuszy lub zarząd przedsiębiorstwa.

Według Agrawala i Knoebera (1996, s. 377) do mechanizmów kontroli kosztów agencji powstających między kierownictwem a akcjonariuszami przedsiębiorstwa zalicza się:

- posiadanie akcji przez menedżerów przedsiębiorstwa,

- posiadanie akcji przez instytucje,

- posiadanie udziałów przez właścicieli pakietów akcji,

- zatrudnianie menedżerów zewnętrznych do kierowania przedsiębiorstwem,

- politykę zadłużeniową przedsiębiorstwa,

- kontrolę przedsiębiorstwa. Według Ang, Cole i Lina (2000, s. 81)

koszty agencji:

- cechuje odwrotna zależność w stosunku do udziału kierownictwa w kapitale własnym przedsiębiorstwa,

- są wyższe w przypadku, gdy przedsiębiorstwem zarządzają menedżerowie zewnętrzni,

- wzrastają wraz ze wzrostem liczby akcjonariuszy nienależących do kierownictwa spółki,

- ulegają redukcji wraz ze wzrostem kontroli przedsiębiorstwa przez banki.

W kontekście kosztów agencji menedżerowie wykorzystują kapitał własny do sfinansowania projektów inwestycyjnych, jeżeli jest to zgodne $\mathrm{z}$ interesem inwestorów. W przeciwnym razie korzystaja z długu (Dittmar i Thakor 2007, s. 1).

Kierownictwo może także dążyć do powiększenia rozmiarów przedsiębiorstwa ze szkodą dla akcjonariuszy, których celem jest maksymalizacja rynkowej wartości posiadanych akcji. W celu ograniczenia ekspansjonistycznych działań kierownictwa akcjonariusze godzą się na wzrost stopy wypłat dywidend oraz wzrost wykorzystania kapitałów obcych. Chociaż wykorzystanie długu wpływa $\mathrm{z}$ jednej strony na kontrolę kosztów agencji wynikających z konfliktów między akcjonariuszami a kierownictwem, to $z$ drugiej strony przyczynia się do powstania konfliktów między kierownictwem a wierzycielami. Przedsiębiorstwa finansujące się w dużym stopniu kapitałem obcym mogą nie być w stanie wykorzystać opłacalnych okazji inwestycyjnych wskutek konieczności przeznaczenia środków na obsługę istniejącego zadłużenia (por. Booth, Aivazian, Demirguc-Kunt i Maksimovic, 2001, s. 100).

Koszty agencyjne mogą powstać wskutek podejmowania przez kierownictwo działań korzystnych dla akcjonariuszy, ale sprzecznych $\mathrm{z}$ interesem wierzycieli. Aby się zabezpieczyć, wierzyciele zawierają umowy z klauzulami ograniczającymi zdolności operacyjne i inwestycyjne przedsiębiorstwa. Mogą one dotyczyć zakazu zaciągania dodatkowego długu, wielkości wypłat dywidend, dysponowania aktywami spółki czy podejmowania inwestycji obarczonych określonym ryzykiem. Czynnikami redukującymi koszty agencji są w tym przypadku: emisja kapitału zamiennego oraz zabezpieczenie długu na majątku przedsiębiorstwa.

Koszty agencji są wyższe w przypadku przedsiębiorstw rozwijających się, które charakteryzuje większa elastyczność w doborze potencjalnych inwestycji. W ich przypadku obserwuje się (Bhaduri, 2002, s. 660) negatywną relację między długoterminowym kapitałem obcym a przyszłym wzrostem przedsiębiorstwa. Aby złagodzić ten problem, przedsiębiorstwa korzystają z długu krótkoterminowego. Koszty agencji związane z długiem są wyższe w krajach, w których ochrona prawna kredytodawców jest słabsza (Bancel i Mittoo, 2004, s. 128).

Według Lelanda (1998, s. 1213) wzrost kosztów agencji ogranicza poziom zadłużenia i terminy zapadalności długu oraz wpływa na wzrost zysków w przedsiębiorstwie. Zdaniem 
Datty, Iskander-Datty i Ramana (2005, s. 2333) istnieje odwrotna zależność między wielkością akcji będących w posiadaniu kierownictwa przedsiębiorstwa a terminem płatności długu. Poziom zadłużenia spada wraz ze wzrostem udziału kierownictwa w kapitale własnym przedsiębiorstwa. Wiąże się to $\mathrm{z}$ ryzykiem finansowym wynikającym $\mathrm{z}$ braku możliwości dywersyfikacji przez kierownictwo przedsiębiorstwa portfela dłużnych papierów wartościowych (Friend i Lang, 1988, s. 271). Zadłużenie wzrasta natomiast wraz ze wzrostem reputacji kierownictwa (Harris i Raviv, 1991, s. 328).

Menedżerowie mający wyższy udział w kapitale własnym przedsiębiorstwa preferują dług krótkoterminowy, co wiąże się z częstszymi kontrolami ze strony wierzycieli. Menedżerowie o niższym udziale w kapitale własnym przedsiębiorstwa wybierają natomiast dług długoterminowy (Datta, Iskander-Datta i Raman, 2005, s. 2348-2349). Menedżerowie wybierają niższy poziom zadłużenia w relacji do wielkości optymalnej z uwagi na (Berger, Ofek, Yermack, 1997, s. 1411; Fosberg, 2004, s. 31-32):

- redukcję ryzyka, przekładającego się na zachowanie przez nich prestiżu i utrzymanie zatrudnienia $\mathrm{w}$ przedsiębiorstwie, którym zarządzają,

- niechęć do działania pod presją, związaną z zobowiązaniami finansowymi.

Kierownictwo przedsiębiorstwa preferuje niższy poziom zadłużenia dla zmniejszenia prawdopodobieństwa bankructwa (Gajdka 2002, s. 194). Konflikt między akcjonariuszami a kierownictwem przejawia się w sposobie redystrybucji wypracowanych przez przedsiębiorstwo zysków. Kierownictwo preferuje reinwestycję zysków nad wypłacanie ich w formie dywidendy akcjonariuszom. Wzrost udziału długu w finansowaniu przedsiębiorstwa redukuje ten konflikt (Harris i Raviv, 1990, s. 321). Pojawienie się kapitału obcego powoduje zmniejszenie wolnej gotówki, którą może dysponować zarząd, a wobec konieczności jej przeznaczenia na obsługę długu, ma on mniejsze możliwości podejmowania decyzji niekorzystnych dla właścicieli (Harris i Raviv, 1991, s. 300; Booth, Aivazian, Demirguc-Kunt i Maksimovic, 2001, s. 100).

Jeżeli zadłużenie powoduje spadek kosztów agencji między właścicielami a kierownictwem, zaś akcjonariusze są w stanie lepiej kontrolować zarząd, oczekuje się, że wyższemu ich udziałowi w kapitale własnym towarzyszy niższy udział długu (Gajdka, 2002, s. 201). Wyniki tego typu rozważań nie są jednak jednoznaczne. Według Agrawala i Nagarajana (1990, s. 1325) wyższy udział kierownictwa w kapitale własnym prowadzi do spadku zadłużenia. Innego zdania jest Mehran (1992, s. 539), który stwierdził dodatnią relację między udziałem kierownictwa w kapitale własnym a wielkością kapitału obcego.

Przyjmując, że strony zawartej umowy dążą do maksymalizacji swoich korzyści, zarząd przedsiębiorstwa nie zawsze działa w interesie jego właścicieli. Uwzględniając zachowanie kierownictwa, oparte na działaniu sprzecznym z interesem właścicieli przedsiębiorstwa, kapitałodawcy podejmuja próby takiego kształtowania struktury kapitałowej, która z jednej strony wyeliminuje negatywne bodźce determinujące zachowanie zarządu, z drugiej zaś wpłynie na prawidłową wycenę emitowanych papierów wartościowych (Heinkel 1982, s. 1141).

Koszty agencji wynikające $\mathrm{z}$ konfliktu między akcjonariuszami a kierownictwem oraz między kierownictwem (akcjonariuszami) a wierzycielami przedsiębiorstwa ulegają zmianom wraz ze wzrostem udziału zadłużenia. Finansowanie kapitałem obcym przyczynia się z jednej strony do redukcji kosztów agencji wynikających $\mathrm{z}$ konfliktu między akcjonariuszami, a kierownictwem, $\mathrm{z}$ drugiej zaś powoduje ich wzrost w wyniku konfliktu między kierownictwem a wierzycielami przedsiębiorstwa (Gajdka 2002, s. 223). Ten drugi konflikt może jednak ulec redukcji w przypadku wzrostu udziału rzeczowych aktywów trwałych, stanowiących zabezpieczenie spłaty długu.

Wpływ kosztów agencji w kontekście determinant struktury kapitałowej jest uwzględniany kompleksowo jako łączny efekt oddziaływania tarczy podatkowej, kosztów bankructwa oraz kosztów agencji (Miao, 2005, s. 2621). Optymalna struktura kapitałowa odzwierciedla te trzy czynniki (Leland i Toft, 1996, s. 987; Leland, 1998, s. 1213). Wraz ze wzrostem zadłużenia wzrasta rynkowa wartość akcji przedsiębiorstwa o wielkość tarczy podatkowej. Wartość ta ulega zmniejszeniu o wielkość kosztów bankructwa oraz kosztów agencji.

\section{Metodologia badania}

W ramach teorii substytucji poddano analizie hipotezy w teorii uwzględniającej koszty bankructwa oraz agencji. 


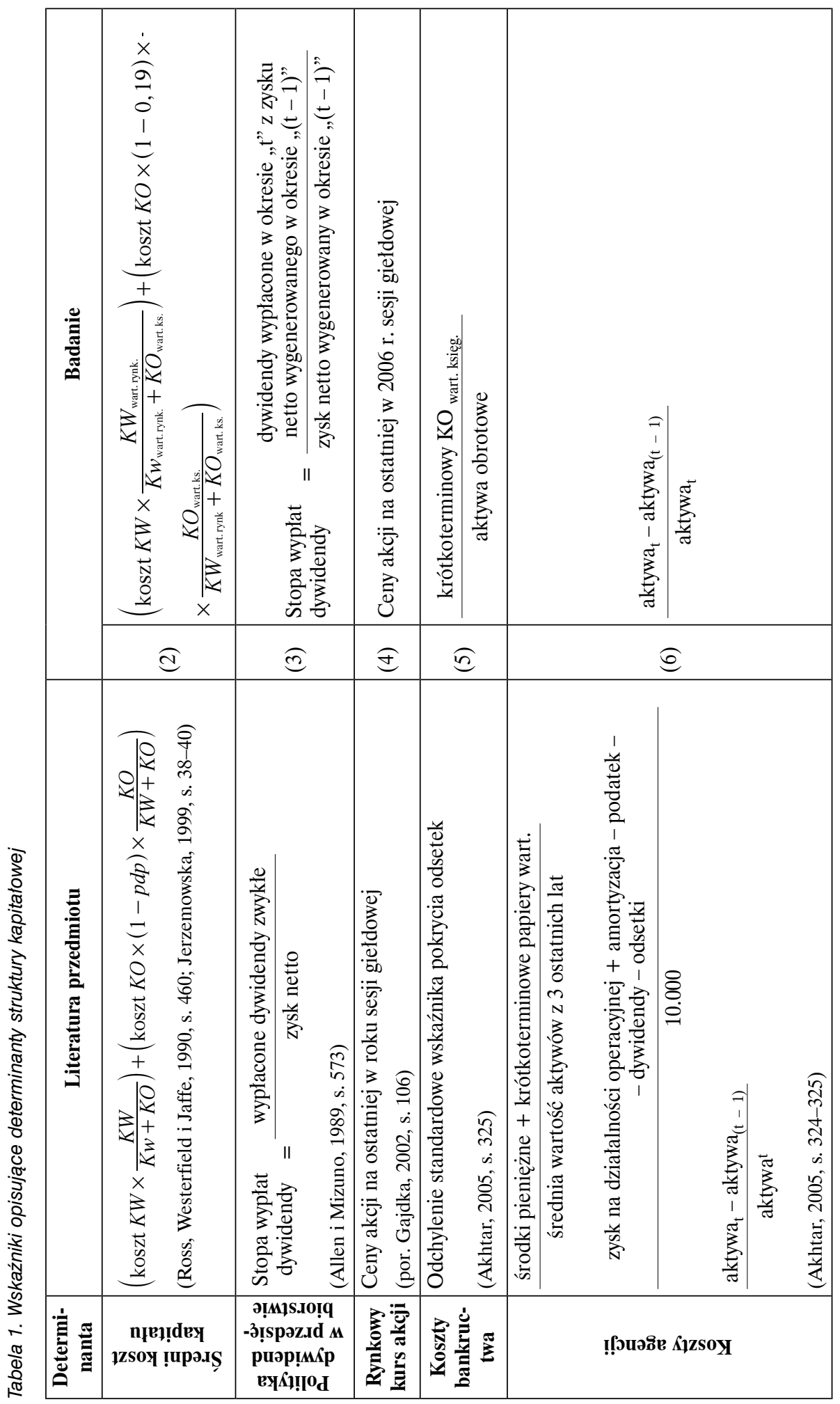




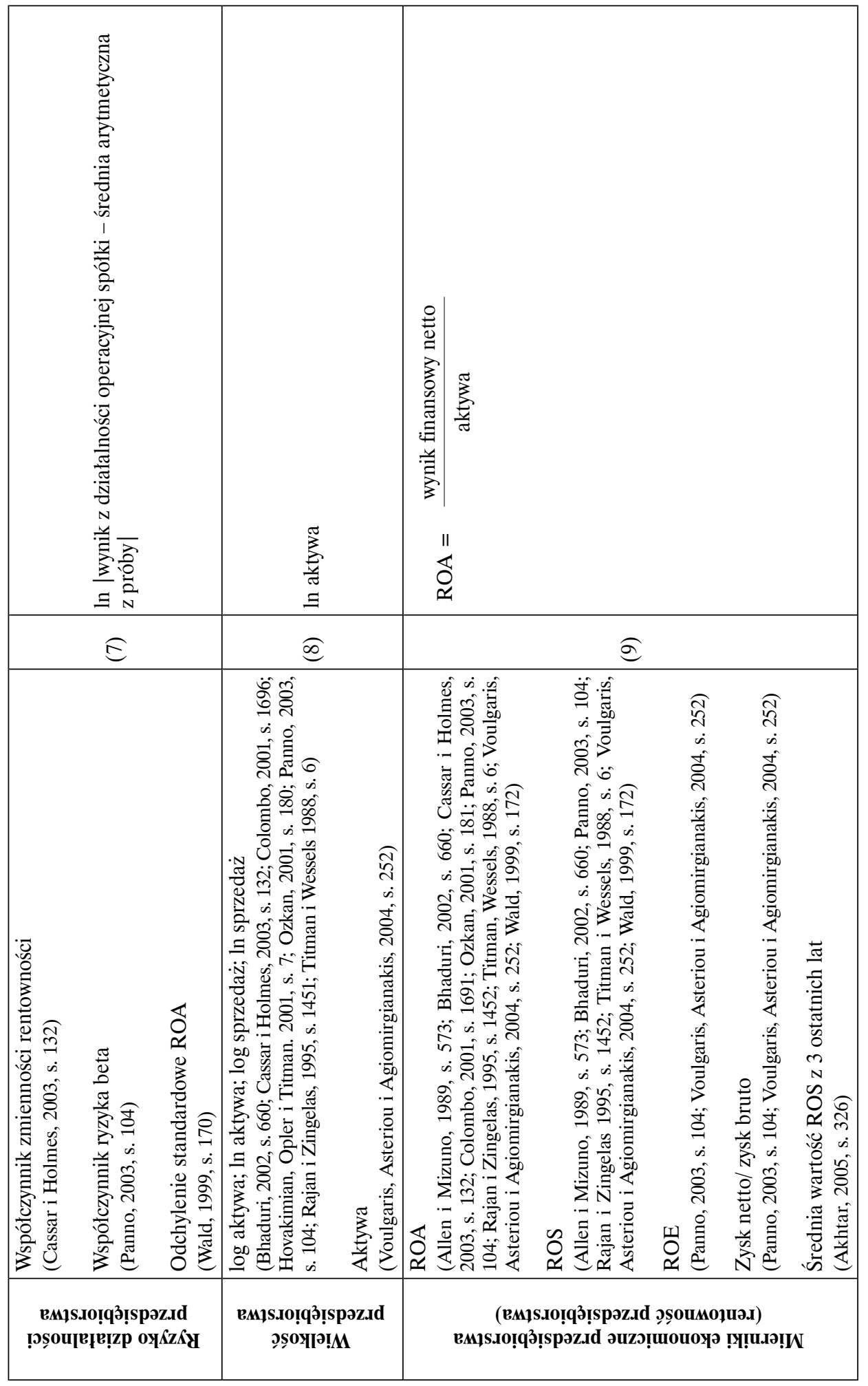

Wydział Zarządzania UW ～DOI 10.7172/1733-9758.2012.14-15.3 


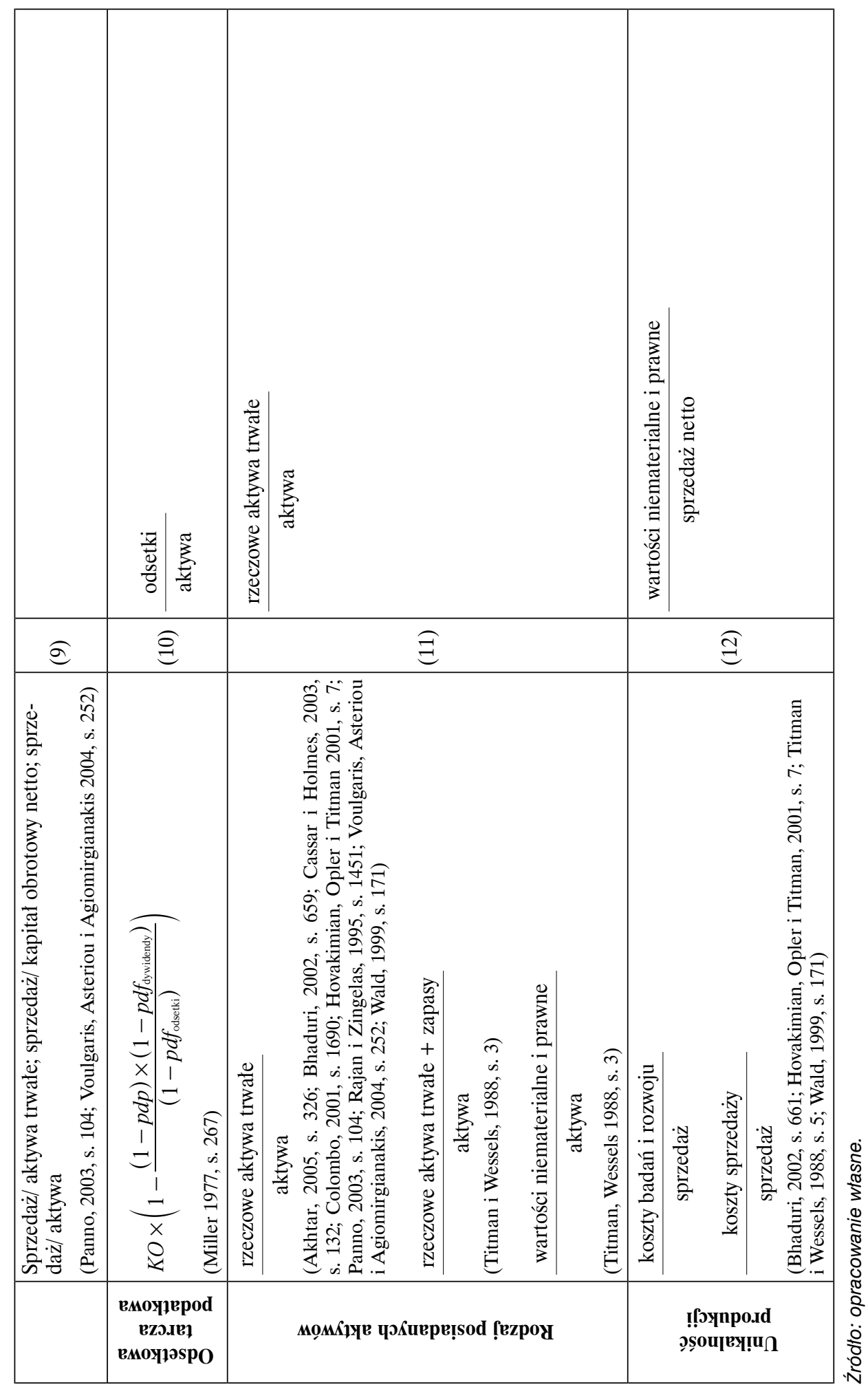


Przedmiotowy zakres badania obejmuje identyfikację związków zachodzących między determinantami struktury kapitałowej oraz analizę siły i kierunku ich wpływu na strukturę kapitałową przedsiębiorstwa. Empiryczna weryfikacja hipotez dokonana została w ramach teorii substytucji. Do zdefiniowania hipotez wykorzystano determinanty struktury kapitałowej, których wartość określona została za pomocą testów (wskaźników) weryfikacyjnych (tabela 1 ).
Na potrzeby niniejszej pracy przyjęto za strukturę kapitałową wskaźnik zadłużenia w postaci:

kapitał obcy w wartości księgowej

kapitał własny w wartości rynkowej +

+ kapitał obcy w wartości księgowej

Kapitał własny w wartości rynkowej jest iloczynem łącznej liczby akcji na koniec 2006 r. oraz ceny akcji na ostatniej w 2006 r.

Tabela 2. Populacja generalna spółek notowanych na GPW w Warszawie w każdym roku okresu 2000-2006

\begin{tabular}{|c|c|c|}
\hline Branża & $\begin{array}{l}\text { Liczba } \\
\text { spólek }\end{array}$ & Nazwy spółek \\
\hline Budowlana & 28 & $\begin{array}{l}\text { Atlantis, Budimex, Budopol, Echo, Elektrobudowa, } \\
\text { Elektromontaż-Export, Elektromontaż-Warszawa, } \\
\text { Energomontaż-Południe, Energomontaż-Północ, Energopol, } \\
\text { Hydrobudowa-Śląsk, Instal-Kraków, Instal-Lublin, Irena, } \\
\text { Krosno, Lentex, Mostostal-Export, Mostostal-Płock, } \\
\text { Mostostal-Warszawa, Mostostal-Zabrze, Naftobudowa, Pemug, } \\
\text { Polnord, Prochem, Projprzem, Ropczyce, Wandalex, ZPUE }\end{array}$ \\
\hline Chemiczna & 7 & $\begin{array}{l}\text { Boryszew, PKN Orlen, Permedia, Pollena, Stomil-Sanok, } \\
\text { Suwary, Unimil }\end{array}$ \\
\hline Drzewno-papiernicza & 7 & $\begin{array}{l}\text { Forte, Grajewo, Kompap, Łda Invest, Paged, Swarzędz, } \\
\text { Świecie }\end{array}$ \\
\hline Elektroenergetyczna & 3 & Będzin, Elektrim, Energoaparatura \\
\hline Elektromaszynowa & 12 & $\begin{array}{l}\text { Amica, Apator, Hydrotor, Kable, Kopex, Polna, Ponar, } \\
\text { Rafako, Relpol, Remak, ZEG, ZREW }\end{array}$ \\
\hline Farmaceutyczna & 2 & Farmacol, PGF \\
\hline Handel & 3 & 7 Bulls, Ampli, Tim \\
\hline Hotelarska & 1 & Orbis \\
\hline Informatyczna & 10 & $\begin{array}{l}\text { Comarch, Computerland, CSS, Elzab, Internet Group, } \\
\text { Invar\&Biuro System, Optimus, Prokom, Simple, Talex }\end{array}$ \\
\hline Metalowa & 10 & $\begin{array}{l}\text { Ferrum, Hutmen, Impexmetal, Kęty, KGHM, Mennica, } \\
\text { Odlewnie, Stalexport, Stalprodukt, Stalprofil }\end{array}$ \\
\hline Motoryzacyjna & 2 & Dębica, Groclin \\
\hline Przemysł lekki & 9 & $\begin{array}{l}\text { Bytom, Lubawa, Masters, Protektor, Próchnik, Sanwil, Skotan, } \\
\text { Vistula, Wistil }\end{array}$ \\
\hline Spożywcza & 11 & $\begin{array}{l}\text { Beef-San, Ekodrob, Indykpol, Jutrzenka, Kruszwica, Mieszko, } \\
\text { Pepees, Strzelec, Wawel, Wilbo, Żywiec }\end{array}$ \\
\hline Telekomunikacyjna & 2 & Netia, Telekomunikacja Polska \\
\hline Usługi inne & 4 & Best, Gant, Kogeneracja, TUP \\
\hline Wydawnicza & 3 & Agora, Muza, PPWK \\
\hline Pozostałe & 4 & Efekt, Fasing, Novita, Prosper \\
\hline
\end{tabular}

Źródło: opracowanie własne na podstawie Roczników Giełdowych GPW w Warszawie oraz stron internetowych spółek. 
sesji giełdowej. Kapitał obcy w wartości księgowej obejmuje zobowiązania długoi krótkoterminowe (w tym pochodne instrumenty finansowe i fundusze specjalne), bez rezerw na zobowiązania oraz rozliczeń międzyokresowych według stanu na koniec 2006 roku.

Badaniu poddano próbę losową, obejmującą 39 spółek akcyjnych, wyodrębnioną z populacji generalnej 118 spółek, należących do różnych branż (z wyłączeniem banków, zakładów ubezpieczeń oraz funduszy inwestycyjnych), które w każdym roku okresu 2000-2006 notowane były na Giełdzie Papierów Wartościowych w Warszawie.

Z uwagi na wysoką reprezentatywność wyników badania zrealizowano, opierając się na próbie losowej, wyodrębnionej ze skończonej populacji generalnej, o przeliczalnej liczbie elementów za pomoca metody doboru losowego prostego, zależnego (bez zwracania). Na potrzeby niniejszych badań operat losowania, czyli wykaz (lista) wszystkich ponumerowanych elementów populacji liczy 118 spółek (tabela 2). Pozwala on wybrać jednostki ze zbiorowości generalnej przez losowe generowanie numerów elementów, które znajdą się w próbie (Aczel, 2005, s. 192). Metody doboru losowego polegają na znanym i określonym prawdopodobieństwie dostania się każdej jednostki do próby (Mynarski, 2000, s. 22). Dobór losowy prosty jest najprostszym sposobem doboru próby do badań. Polega on na bezpośrednim i nieograniczonym wyborze jednostek badania do próby statystycznej wprost $\mathrm{z}$ populacji generalnej (Mynarski, 2000, s. 23). Jeżeli zbiorowość generalna jest niewielka, wówczas stosowane jest losowanie zależne (Stanisz, 2001, s. 17). Dobór losowy prosty, zależny (bezzwrotny) polega na niezwracaniu wylosowanych jednostek $\mathrm{z}$ powrotem do populacji, skutkiem czego każda wylosowana jednostka już nie uczestniczy w dalszym losowaniu, a wybór pozostałych elementów zależy od rezultatów wcześniejszego losowania (Mynarski, 2000, s. 24). Zatem każda jednostka ma jednakowa szansę znalezienia się $\mathrm{w}$ próbie.

Liczebność próby do badań ustalono na podstawie wylosowanej wcześniej metodą doboru losowego prostego, zależnego próby wstępnej. Poszczególne jednostki badania (spółki) należące do populacji uporządkowane zostały alfabetycznie i oznaczone losami (numerami) od 1 do 118, a następnie umieszczone w urnie. Po dokładnym ich wymieszaniu wylosowano do próby wstępnej 10 spółek (tabela 3 ).

Niezbędną (minimalną) liczebność próby do badań, pozwalającą na utrzymanie uzyskanych oszacowań w granicach określonego losowego błędu średniego próby, tj. na zachowanie założonego z góry poziomu dokładności (precyzji) badania (dla cech ilościowych i skończonej populacji) przedstawia poniższy wzór (Mynarski 2000, s. 47):

wariancja z próby wstępnej

$\frac{\text { (dopuszczalny maksymalny błąd szacunku średniej) }^{2}}{\text { (wartość krytyczna odczytana z tablicy rozkładu }_{\text {t-Studenta })^{2}}}+\frac{\text { wariancja z próby wstępnej }^{\text {liczebność populacji }}}{\text { lis }}$

Tabela 3. Losowa próba wstępna obejmująca spótki notowane na GPW w Warszawie w każdym roku okresu 2000-2006, służąca wyznaczeniu liczebności losowej próby badawczej

\begin{tabular}{|l|c|l|}
\hline \multicolumn{1}{|c|}{ Branża } & Ilość spółek & \multicolumn{1}{c|}{ Nazwy spółek } \\
\hline Budowlana & 3 & Echo, Mostostal-Płock, Prochem \\
\hline Chemiczna & 1 & PKN Orlen \\
\hline Elektromaszynowa & 2 & Kable, Relpol \\
\hline Informatyczna & 2 & Computerland, CSS \\
\hline Motoryzacyjna & 1 & Dębica \\
\hline Spożywcza & 1 & Jutrzenka \\
\hline
\end{tabular}

Źródło: opracowanie własne na podstawie Roczników Giełdowych GPW w Warszawie oraz stron internetowych spótek. 
Jeżeli obliczona liczebność próby do badań (po zaokrągleniu w górę $\mathrm{z}$ dokładnością do miejsc całkowitych) jest mniejsza od liczebności próby wstępnej, wówczas liczebność próby wstępnej traktowana jest jako liczebność próby badawczej. W przeciwnym razie dolosowana zostanie różnica między większą liczebnością próby do badań, a niższą liczebnością próby wstępnej (Mynarski 2000, s. 47). Liczebność próby badawczej wyliczono na 38,38 jednostek, co po zaokrągleniu w górę do jedności daje 39 spółek. Ponieważ próba wstępna liczyła 10 spółek, dolosowano z populacji generalnej za pomocą metody doboru losowego prostego, zależnego 29 dodatkowych spółek. W tabeli 4 przedstawiono liczebność losowej próby badawczej.

Wyliczona liczebność próby badawczej świadczy o ich ugruntowanej pozycji na rynku i stabilności finansowej. Zarówno ciągłość obecności na GPW w Warszawie, jak i sposób losowania spółek sprawiają, że przeprowadzone na podstawie wyodrębnionej próby losowej obliczenia można uznać za wiarygodne. Dzięki temu można przyjąć, iż uzyskane wyniki i relacje dotyczące próby, w skład której wchodzą wylosowane do badań przedsiębiorstwa odnoszą się również do całej populacji przedsiębiorstw notowanych na GPW w Warszawie. Wnioskowanie statystyczne odnośnie do otrzymanych wyników próby losowej daje zatem podstawy do ich uogólnienia na całą zbiorowość generalną.

Do obliczeń wykorzystano dane finansowe zawarte w sprawozdaniach finansowych, dokumentach spółek oraz publika-

Tabela 4. Losowa próba badawcza obejmująca spółki notowane na GPW w Warszawie w każdym z lat okresu 2000-2006

\begin{tabular}{|l|c|l|}
\hline \multicolumn{1}{|c|}{ Branża } & Liczba spólek & \multicolumn{1}{c|}{ Nazwy spólek } \\
\hline Budowlana & 8 & $\begin{array}{l}\text { Budimex, Echo, Elektrobudowa, Lentex, Mostostal-Płock, } \\
\text { Mostostal-Warszawa, Mostostal-Zabrze, Prochem }\end{array}$ \\
\hline Chemiczna & 3 & Boryszew, PKN Orlen, Suwary \\
\hline Drzewno-papiernicza & 1 & Forte \\
\hline Elektromaszynowa & 6 & Apator, Kable, Ponar, Rafako, Relpol, Remak \\
\hline Handel & 1 & Ampli \\
\hline Hotelarska & 1 & Orbis \\
\hline Informatyczna & 6 & Comarch, Computerland, CSS, Elzab, Prokom, Talex \\
\hline Metalowa & 4 & Kęty, KGHM, Stalprodukt, Stalprofil \\
\hline Motoryzacyjna & 2 & Dębica, Groclin \\
\hline Przemysł lekki & 1 & Vistula \\
\hline Spożywcza & 2 & Jutrzenka, Mieszko \\
\hline Telekomunikacyjna & 1 & Telekomunikacja Polska \\
\hline Usługi inne & 1 & Kogeneracja \\
\hline Wydawnicza & 2 & Agora, PPWK \\
\hline
\end{tabular}

Źródło: opracowanie własne na podstawie Roczników Giełdowych GPW w Warszawie oraz stron internetowych spółek.

uznać można za dużą. Stanowi ona bowiem trzecią część liczebności zbiorowości generalnej. Przyjmuje się zatem, że tak wylosowana próba jest reprezentatywna w stosunku do całej populacji.

W populacji generalnej uwzględniono spółki, które nieprzerwanie przez okres siedmiu lat obecne były na Giełdzie, co cjach giełdowych (Roczniku Giełdowym, Biuletynie Rocznym GPW w Warszawie). W badaniu przyjęto testy weryfikacyjne opisujące determinanty struktury kapitałowej (zmienne niezależne) oraz strukturę kapitałową (zmienna zależna) dla poszczególnych spółek wyliczone na poziomie danych z 2006 roku. 
Teoria uwzględniającej koszty bankructwa

W ramach teorii uwzględniającej koszty bankructwa do badań przyjęto 3 hipotezy:

1. Wzrost kosztów bankructwa, wzrost ryzyka działalności przedsiębiorstwa oraz wzrost unikalności produkcji powoduje spadek wskaźnika zadłużenia.

2. Wzrost wielkości przedsiębiorstwa, wzrost rentowności przedsiębiorstwa oraz wzrost udziału rzeczowych aktywów trwałych powoduje wzrost wskaźnika zadłużenia.

3. Wzrost średniego kosztu kapitału powoduje spadek odsetkowej tarczy podatkowej, spadek rynkowego kursu akcji oraz spadek wskaźnika zadłużenia.

Do analizy hipotez 1 do 3 wykorzystano testy opisujące zmienne niezależne w postaci kosztów bankructwa - wzór (5), unikalności produkcji zapisanej wzorem (12), wielkości przedsiębiorstwa obliczonej według wzoru (8), ryzyka działalności przedsiębiorstwa opisanego wzorem (7), rentowności (deficytowości) przedsiębiorstwa określonej we wzorze (9), rodzaju posiadanych aktywów opisanego wzorem (11), średniego kosztu kapitału podanego w formule (2) oraz zmienne zależne: rynkowy kurs akcji - wzór (4), odsetkową tarczę podatkową określoną wzorem (10) i strukturę kapitałową (wskaźnik zadłużenia), opisany we wzorze (1).

Hipotezy 1 i 2 zweryfikowano za pomocą regresji wielokrotnej i korelacji wielokrotnej (metoda właściwa dla modelu $\mathrm{z}$ jedną zmienną zależną i wieloma zmiennymi niezależnymi). Hipotezę 3 zweryfikowano za pomoca analizy kanonicznej (metoda właściwa dla modelu $\mathrm{z}$ wieloma zmiennymi zależnymi i z jedną lub wieloma zmiennymi niezależnymi).

Przedstawione przez autora testy weryfikacyjne uznano za najbardziej reprezentatywne w warunkach polskiej gospodarki. Do analizy kosztów bankructwa wykorzystano wskaźnik opisany wzorem (5). Stanowi on odwrotność wskaźnika bieżącej płynności finansowej. Wzrost tego wskaźnika będzie świadczył o utracie przez przedsiębiorstwo zdolności do bieżącego wywiązywania się z zobowiązań, a w konsekwencji - wzroście kosztów bankructwa. Do pomiaru unikalności produkcji wykorzystano wartości niematerialne i prawne. Uznano bowiem, że wchodzące w ich skład koszty zakończonych prac rozwojowych, patenty, licencje, koncesje, oprogramowanie komputerowe najlepiej mogą świadczyć o unikalności danej produkcji. Taką unikalność nie zawsze utożsamiają koszty sprzedaży, obejmujące koszty marketingowe, reklamy i promocji, koszty związane $\mathrm{z}$ wysyłką i transportem sprzedanych produktów. Sprzedaż netto obejmuje przychody ze sprzedaży produktów, towarów, materiałów i usług.

Wstępne badania w ramach hipotezy 1 przeprowadzono dla próby losowej 39 spółek. Sporządzono wielokrotną regresję liniową (model 1). Model regresji liniowej przybiera postać:

$$
\begin{aligned}
\mathrm{WZ} & =0,828463 \text { Ryzyko }+0,052434 \mathrm{~KB}- \\
& -0,187838 \mathrm{UP}+7,503351 .
\end{aligned}
$$

Model 1 nie jest istotny $(\mathrm{p}>\alpha)$. Żadna zmienna niezależna $w$ nim zawarta nie ma zatem istotnego wpływu na zmienna zależną. Nie było więc podstaw do interpretacji tych zmiennych. Również wspó1czynniki korelacji cząstkowych i korelacji wielokrotnej dla tych zmiennych okazały się nieistotne statystycznie z $\mathrm{p}>\alpha$. Nie było zatem podstaw do ich interpretacji. Powyższe wskazuje, że model 1 może zawierać punkty odstające oraz nadmiarowe zmienne niezależne.

Zbadano model 1 pod kątem występowania potencjalnych punktów odstających. W tym celu sporządzono tabelę punktów odstających według przypadków oraz wykresy rozrzutu zmiennych niezależnych względem WZ. Usunięto potencjalne punkty odstające:

- jedną spółkę (Mieszko) - do badania przyjęto 38 spółek (model 2),

- dziewięć spółek (Groclin, Jutrzenka, KGHM, Orbis, PKN Orlen, PPWK, Stalprodukt, TP, Vistula) - do badania przyjęto 30 spółek (model 3).

Do dalszego badania przyjęto model 3 z uwagi na wyższy skorygowany współczynnik determinacji $(0,12815083)$ w porównaniu z modelem $2(0,06515168)$.

W przypadku modelu 3 spadła nieistotność korelacji wielorakiej (do poziomu 0,8874), wzrósł współczynnik determinacji i skorygowany współczynnik determinacji (odpowiednio do poziomu: 0,22 i 0,13). Ponadto zmienna niezależna KB okazała się istotna statystycznie $(\mathrm{p}<\alpha)$. Współczynnik BETA dla tej zmiennej przyjmuje najwyższą wartość $(0,435047)$. Również udział 
standardowego błędu w ocenie parametru opisującego KB kształtuje się na akceptowalnym poziomie $40 \%$.

W celu stwierdzenia ewentualnej współliniowości zmiennych niezależnych zbadano korelację liniową Pearsona między zmiennymi w modelu 3. Współczynniki korelacji Pearsona między zmiennymi niezależnymi okazały się nieistotne statystycznie z $\mathrm{p}>\alpha$. Nie było zatem podstaw do ich interpretacji. Na współliniowość i nadmiarowość zmiennych niezależnych: „ryzyko” i „UP” wskazują wartości współczynnika determinacji między tymi zmiennymi niezależnymi a wszystkimi pozostałymi zmiennymi niezależnymi (kształtujące się na poziomie odpowiednio: 0,055 i 0,06 , a zatem wyższym niż wartość tego miernika dla KB: 0,007$)$ oraz tolerancji dla tych zmiennych (kształtujące się na poziomie odpowiednio: 0,945 i 0,939 , a więc niższym niż wartość tego miernika dla KB: 0,993$)$. O tym, że zmienna niezależna KB jest najmniej nadmiarowa, świadczy również jej najwyższe $\mathrm{i}$ istotne $(\mathrm{p}<\alpha)$ skorelowanie ze zmienną zależną $\mathrm{WZ}$ na poziomie 0,44 .

Potwierdzenie wyników w zakresie współliniowości zmiennych niezależnych stanowi podsumowanie regresji krokowej postępującej. Otrzymane wyniki świadczą o tym, że zmienne niezależne „ryzyko” i UP są współliniowe. Okazało się ponadto, że obie są nadmiarowe. Zostały zatem wyeliminowane $\mathrm{z}$ modelu regresji, który przyjmuje postać (model 4):

$$
\mathrm{WZ}=0,23952 \mathrm{~KB}+6,948966 .
$$

Model 4 jest istotny statystycznie $(\mathrm{p}<\alpha)$. Poprawiły się również opisujące go mierniki. Wzrosła wartość skorygowanego współczynnika determinacji (do poziomu: 0,16). Spadł udział standardowego błędu w ocenie parametru opisującego KB (39\%). Nadal pozostaje jednak nieistotny wyraz wolny, chociaż jego nieistotność zmniejszyła się ( $\mathrm{z} p=0,36$ do 0,24$)$.

W celu eliminacji potencjalnych punktów odstających oraz wyboru ostatecznej postaci funkcji regresji sporządzono dla modelu 4 diagram korelacyjny zmiennej zależnej WZ względem KB. Nie wskazuje on na istnienie punktów odstających. W celu wyboru do analizy reszt postaci funkcji zbadano 4 pomocnicze modele (w postaci linearyzowalnej funkcji kwadratowej, wielomianowej stopnia trzeciego, potęgowej oraz wykładniczej), z których wybrany zostanie ten o maksymalnej mierze dopasowania (skorygowanym współczynniku determinacji).

Analizę założeń dotyczących reszt przeprowadzono na podstawie funkcji potęgowej (model 5) z uwagi na maksymalną wartość skorygowanego współczynnika determinacji $(0,20405050)$, wyższą niż w modelu $4(0,16003382)$.

Model 5 przyjmuje postać:

$\log \mathrm{WZ}=-0,216696+0,842198 \log \mathrm{KB}$.

Model ten jest istotny statystycznie $(\mathrm{p}<\alpha)$. Pomimo że wzrosła nieistotność wyra$\mathrm{zu}$ wolnego $\mathrm{w}$ porównaniu $\mathrm{z}$ modelem 4 ( $\mathrm{z} p=0,24$ do 0,67$)$, poprawiła się zdecydowanie istotność zlogarytmowanej zmiennej niezależnej KB ( $\mathrm{z}$ p $=0,016$ do $0,007)$. Wzrosła wartość korelacji liniowej Pearsona między „log KB” a „log WZ”. Jej poziom kształtuje się na istotnym, dużym poziomie $(0,48)$. Jest ona jednak dodatnia, co oznacza wzrost WZ wraz ze wzrostem KB. Zależność taka nie odpowiada hipotezie $1 \mathrm{w}$ części dotyczącej wpływu kosztów bankructwa na strukturę kapitałową (zgodnie bowiem $z$ hipotezą 1 wzrost kosztów bankructwa powoduje spadek wskaźnika zadłużenia). Redukcji uległ także udział standardowego błędu w ocenie parametru opisującego „log KB” (z 39 do 34\%).

Zbadano model 5 pod kątem występowania potencjalnych punktów odstających. Usunięto potencjalny punkt odstający (Apator) i dalsze badania przeprowadzono dla zlinearyzowanej funkcji potęgowej o liczebności próby losowej 29 spółek (model 6). Model 6 nie posiada punktów odstających.

Model 6 przyjmuje postać:

$\log \mathrm{WZ}=-0,031299+0,753542 \log \mathrm{KB}$.

Model ten jest istotny statystycznie $(p<\alpha)$. Pomimo że obserwuje się dalszy wzrost nieistotności wyrazu wolnego $\mathrm{w}$ porównaniu $\mathrm{z}$ modelem 7 ( $\mathrm{z}$ p=0,67 do 0,93), poprawiła się zdecydowanie istotność zlogarytmowanej zmiennej niezależnej KB ( $\mathrm{z} p=0,007$ do 0,002). Wzrosła wartość skorygowanego współczynnika determinacji $(0,28)$ oraz korelacji liniowej Pearsona między „log KB”, a „log WZ” $(0,55)$. Korelacja ta, pomimo że istotna i duża, jest jednak dodatnia, co oznacza wzrost WZ wraz ze 
wzrostem KB. Zależność taka nie odpowiada hipotezie $1 \mathrm{w}$ części dotyczącej wpływu kosztów bankructwa na strukturę kapitałową (zgodnie z hipotezą 1 wzrost kosztów bankructwa powoduje bowiem spadek wskaźnika zadłużenia). Redukcji uległ także udział standardowego błędu w ocenie parametru opisującego „log KB” (z 33 do $29 \%$ ). W związku z powyższym można uznać, że model 6 jest dobrze dopasowany do danych empirycznych (dobrze wyjaśnia badane zjawisko). Nie potwierdza on jednak hipotezy 1.

Model 6 jest liniowy względem parametrów. Na poziomie istotności $\alpha=0,05$ odrzucono hipotezę o nieistotności liniowego związku między zmiennymi „log KB” i „log WZ” $(p<\alpha)$. Potwierdza to wykres rozrzutu reszt względem wartości przewidywanych, który układa się w formie równomiernej chmury punktów i nie sugeruje wyraźnego wzoru.

W badaniu uwzględniono próbę losową obejmującą 29 spółek, a zatem liczba obserwacji jest większa niż liczba szacowanych parametrów.

Reszty są nieskorelowane (brak jest autokorelacji). Statystyka testowa DurbinaWatsona przyjmuje wartość zbliżoną do 2 (1,610374).

Wykres rozrzutu reszt względem wartości przewidywanych wskazuje na występowanie homoscedastyczności - reszty nie są zróżnicowane (nie wzrastają ani nie maleją) względem wartości teoretycznych. Zachowane zostaje zatem założenie o stałości wariancji reszt.

Na rozkład normalny składników losowych wskazuje zarówno wykres normalności reszt, jak i histogram reszt. Reszty są zgodne $\mathrm{z}$ rozkładem normalnym. Punkty układają się bowiem wokół linii prostej (nie odchylają się od tej linii).

Z przeprowadzonych badań wynika, iż wzrost kosztów bankructwa powoduje wzrost wskaźnika zadłużenia. Wyniki obliczeń nie potwierdzają zatem hipotezy 1 , zgodnie z którą wzrost kosztów bankructwa, wzrost ryzyka działalności przedsiębiorstwa oraz wzrost unikalności produkcji powodują spadek wskaźnika zadłużenia. O powyższym świadczy dodatni współczynnik kierunkowy regresji pod postacią linearyzowalnej funkcji potęgowej (model 6), a także współczynnik korelacji liniowej Pearsona dla tego modelu, który przyjmuje istotną, wysoką wartość dodatnią $(0,55)$ (tabela 5). Ponadto pozostałe zmienne niezależne (ryzyko i unikalność produkcji) okazały się współliniowe i nadmiarowe.

Chociaż model 6 jest istotny statystycznie $(\mathrm{p}<\alpha)$ i spełnia założenia nałożone na reszty modelu, nie potwierdza on hipotezy $1 \mathrm{w}$ ramach teorii uwzględniającej koszty bankructwa. Dlatego też odrzucono hipotezę 1, ponieważ nie została ona potwierdzona empirycznie.

Wstępne badania w ramach hipotezy 2 przeprowadzono dla próby losowej 39 spółek. Sporządzono wielokrotną regresję liniową (model 1). Model regresji liniowej przybiera postać:

$$
\begin{aligned}
\mathrm{WZ} & =-0,56427 \mathrm{ROA}+0,00626 \mathrm{RPA}+ \\
& +0,20093 \mathrm{WP}+20,39469 .
\end{aligned}
$$

Wartość $\mathrm{p}<\alpha$ dla modelu 1 wskazuje, że znajduje się $\mathrm{w}$ nim przynajmniej jedna istotna zmienna niezależna. Jedyna istotna w modelu zmienna niezależna ROA $(\mathrm{p}<\alpha)$ posiada ujemny współczynnik kierunkowy (zatem wzrost ROA powoduje spadek WZ, co przeczy hipotezie 2). Pozostałe wskaźniki (RPA, WP) posiadają wprawdzie dodatnie współczynniki kierunkowe (co jest zgodne z hipotezą 2), lecz są one nieistotne statystycznie $(p>\alpha)$ i obarczone wysokimi błędami szacunku, których udział w ocenie parametrów znacznie przekracza dopuszczalny limit precyzji szacunku $50 \%$. Powyższe wskazuje, że model 1 może zawierać punkty odstające oraz nadmiarowe zmienne niezależne. Model regresji wyjaśnia tylko $13,02 \%$ zmienności WZ

Tabela 5. Podsumowanie wyników $w$ ramach hipotezy 1

\begin{tabular}{|l|l|c|}
\hline \multicolumn{1}{|c|}{ Wyszczególnienie } & Wartość & p \\
\hline Model regresji (skorygowany współczynnik determinacji) & 0,27610 & 0,002018 \\
\hline Log KB (współczynnik kierunkowy) & 0,75354 & 0,002018 \\
\hline Współczynik korelacji liniowej Pearsona & 0,54951 & 0,002018 \\
\hline
\end{tabular}

Źródło: opracowanie własne. 
(skorygowany współczynnik determinacji). Wartość współczynnika determinacji na poziomie 0,2 oznacza, że $20 \%$ ogólnej zmienności WZ zostało wyjaśnione przez model. Wzrost rentowności przedsiębiorstwa o $1 \%$ powoduje spadek wskaźnika zadłużenia średnio o $0,56427 \%$, przy pozostałych zmiennych niezależnych pozostających na stałym poziomie. Na przedstawioną prawidłowość wskazuje również współczynnik korelacji cząstkowej Kendalla na poziomie $-0,443843$. Ukazuje on wkład ROA do modelu $1 \mathrm{z}$ wyłączeniem oddziaływania na ten zwiazek rodzaju posiadanych aktywów i wielkości przedsiębiorstwa. Związek między ROA a WZ jest umiarkowany i ujemny (znacznie jednak wyższy niż związek między pozostałymi zmiennymi niezależnymi i WZ). Oznacza on spadek zadłużenia wraz ze wzrostem rentowności. Natężenie łącznego oddziaływania na WZ zmiennych niezależnych: ROA, RPA, WP jest umiarkowane i wynosi 0,44592148.

Ponieważ zmienne RPA i WP są nieistotne, nie było więc podstaw do ich interpretacji. Nieistotne $(\mathrm{z} p>\alpha)$ są również współczynniki korelacji cząstkowej dla tych zmiennych. Także one nie mogą być zatem interpretowane.

Sporządzony model 1 nie odpowiada hipotezie 2, zgodnie z którą wzrost zmiennych niezależnych (rentowności przedsiębiorstwa, rodzaju posiadanych aktywów, wielkości przedsiębiorstwa) powoduje wzrost wskaźnika zadłużenia.

Zbadano model 1 pod kątem występowania potencjalnych punktów odstających. W tym celu sporządzono tabelę punktów odstających według przypadków oraz wykresy rozrzutu zmiennych niezależnych względem WZ. Usunięto potencjalne punkty odstające:

- jedną spółkę (Mieszko) - do badania przyjęto 38 spółek (model 2),

- sześć spółek (Apator, KGHM, Mostostal-Zabrze, PKN Orlen, Stalprodukt, TP) - do badania przyjęto 33 spółki (model 3).

Do dalszego badania przyjęto model 2 z uwagi na najwyższy skorygowany współczynnik determinacji $(0,13615352)$ w porównaniu $\mathrm{z}$ modelem $1(0,13017562)$ oraz modelem $3(0,09700677)$. Model 2 jest istotny z $\mathrm{p}<\alpha$. Również zmienna ROA jest nadal istotna $(\mathrm{p}<\alpha)$, zmniejszyła się jednak nieistotność pozostałych zmiennych nieza- leżnych. Wzrosła również korelacja wieloraka (z poziomu 0,446 do 0,454 ).

W celu stwierdzenia ewentualnej współliniowości zmiennych niezależnych zbadano korelację liniową Pearsona między zmiennymi w modelu 2. Współczynniki korelacji liniowej Pearsona między zmiennymi niezależnymi okazały się nieistotne statystycznie $\mathrm{z} p>\alpha$. Nie było zatem podstaw do ich interpretacji. Na współliniowość i nadmiarowość zmiennych niezależnych RPA i WP wskazują wartości współczynnika determinacji między tymi zmiennymi niezależnymi a wszystkimi pozostałymi zmiennymi niezależnymi (kształtujące się na poziomie odpowiednio: 0,097 i 0,096 a zatem wyższym niż wartość tego miernika dla ROA: 0,001) oraz tolerancji dla tych zmiennych (kształtujące się na poziomie 0,9 a więc niższym niż wartość tego miernika dla ROA: 0,998 ). O tym, że zmienna niezależna ROA jest najmniej nadmiarowa, świadczy również jej najwyższe $\mathrm{i}$ istotne $(\mathrm{p}<\alpha)$ skorelowanie ze zmienną zależną WZ na poziomie $-0,443$.

W celu potwierdzenia wyników w zakresie współliniowości zmiennych niezależnych wykorzystano regresję krokową postępującą. Otrzymane przy zastosowaniu regresji krokowej postępującej wyniki potwierdziły przypuszczenie, że zmienne niezależne RPA i WP są współliniowe i nadmiarowe. Zostały zatem wyeliminowane $\mathrm{z}$ modelu regresji, który przyjmuje postać (model 4):

$$
\mathrm{WZ}=-0,51451 \mathrm{ROA}+23,56922 .
$$

Model 4 jest istotny statystycznie $(\mathrm{p}<\alpha)$. Wzrosła również istotność ROA $(p=0,006088)$ oraz wyrazu wolnego $(\mathrm{p}=0,000000)$. Wzrosła wartość skorygowanego współczynnika determinacji (do poziomu: 0,1685 ). Spadł udział standardowego błędu w ocenie parametru opisującego ROA (z 35 do 34\%).

W celu eliminacji potencjalnych punktów odstających oraz wyboru ostatecznej postaci funkcji regresji sporządzono dla modelu 4 diagram korelacyjny zmiennej zależnej WZ względem ROA. Sugeruje on, że model 4 może posiadać punkty odstające utworzone przez następujące spółki: Apator, KGHM, Mostostal-Zabrze, Stalprodukt. Zostały one usunięte $\mathrm{z}$ modelu, dla którego wyliczono skorygowany współczynnik determinacji celem sprawdzenia jego dopasowania do danych empirycznych. 
Ponieważ model 5 charakteryzuje się niższym $(0,05001832)$ skorygowanym współczynnikiem determinacji niż model 4 $(0,16845587)$ i dodatkowo jest nieistotny $(p>\alpha)$, dalsze obliczenia przeprowadzono dla modelu 4 . W celu wyboru do analizy reszt postaci funkcji zbadano 4 pomocnicze modele (w postaci linearyzowalnej funkcji kwadratowej, wielomianowej stopnia trzeciego, potęgowej oraz wykładniczej), z których wybrany zostanie ten o maksymalnej mierze dopasowania (skorygowanym współczynniku determinacji).

Analizę założeń dotyczących reszt przeprowadzono, opierając się na funkcji wykładniczej (model 6) z uwagi na maksymalną wartość skorygowanego współczynnika determinacji $(0,27356388)$.

Model 6 przyjmuje postać:

$$
\log \mathrm{WZ}=1,379044-0,019016 \text { ROA. }
$$

Model ten jest istotny statystycznie $(\mathrm{p}<\alpha)$. Wzrosła w porównaniu do modelu 4 istotność ROA ( $\mathrm{z} p=0,006088$ do 0,001058). Wzrosła również wartość skorygowanego współczynnika determinacji (do poziomu: 0,2736). Spadł udział standardowego błędu w ocenie parametru opisującego ROA (z 34 do 27\%).

Zbadano model 6 pod kątem występowania potencjalnych punktów odstających. Usunięto potencjalny punkt odstający (Lentex) i dalsze badania przeprowadzono dla zlinearyzowanej funkcji wykładniczej o liczebności próby losowej 32 spółek (model 7). Model 7 nie posiada punktów odstających.

Model 7 przyjmuje postać:

$$
\log \mathrm{WZ}=1,406036-0,019945 \text { ROA. }
$$

Model ten jest istotny statystycznie $(\mathrm{p}<\alpha)$. Wzrosła w porównaniu do modelu 6 istotność ROA ( $\mathrm{z}$ p=0,001058 do 0,000247). Spadł udział standardowego błędu w ocenie parametru opisującego ROA (z 27 do $24 \%$ ). Wzrosła również wartość skorygowanego współczynnika determinacji (do poziomu: 0,3445) oraz korelacji liniowej Pearsona między ROA a „log WZ” $(-0,6)$. Korelacja ta, pomimo że istotna i duża, jest jednak ujemna, co oznacza spadek WZ wraz ze wzrostem ROA. Zależność taka nie odpowiada hipotezie 2 w części dotyczącej wpływu rentowności przedsiębiorstwa na strukturę kapitałową (zgodnie z hipotezą 2 wzrost rentowności przedsiębiorstwa powoduje bowiem wzrost wskaźnika zadłużenia). W związku z powyższym można uznać, że model 7 jest dobrze dopasowany do danych empirycznych (dobrze wyjaśnia badane zjawisko). Nie potwierdza on jednak hipotezy 2.

Model 7 jest liniowy względem parametrów. Na poziomie istotności $\alpha=0,05$ odrzucono hipotezę o nieistotności liniowego związku między zmiennymi ROA i „log WZ” $(p<\alpha)$. Potwierdza to wykres rozrzutu reszt względem wartości przewidywanych, który nie sugeruje wyraźnego wzoru.

W badaniu uwzględniono próbę losową obejmującą 32 spółki, a zatem liczba obserwacji przewyższa liczbę szacowanych parametrów.

Reszty są nieskorelowane (brak jest autokorelacji). Statystyka testowa DurbinaWatsona przyjmuje wartość zbliżoną do 2 $(2,277834)$.

Wykres rozrzutu reszt względem wartości przewidywanych wskazuje na występowanie homoscedastyczności - reszty nie są zróżnicowane (nie wzrastają ani nie maleją) względem wartości teoretycznych. Zachowane zostaje zatem założenie o stałości wariancji reszt.

$\mathrm{Na}$ rozkład normalny składników losowych wskazuje zarówno wykres normalności reszt, jak i histogram reszt. Reszty są zgodne $\mathrm{z}$ rozkładem normalnym. Punkty układają się bowiem wokół linii prostej (nie odchylają się od tej linii).

Z przeprowadzonych obliczeń wynika, iż wzrost rentowności przedsiębiorstwa powoduje spadek wskaźnika zadłużenia. Wyniki obliczeń nie potwierdzają zatem hipotezy 2, zgodnie z którą wzrost wielkości przedsiębiorstwa, wzrost rentowności przedsiębiorstwa oraz wzrost udziału rzeczowych aktywów trwałych powoduje wzrost wskaźnika zadłużenia. O powyższym świadczy ujemny współczynnik kierunkowy regresji pod postacią linearyzowalnej funkcji wykładniczej, a także współczynnik korelacji liniowej Pearsona dla modelu 7 , który przyjmuje wysoką wartość ujemną $(-0,6)$ (tabela 6). Ponadto pozostałe zmienne niezależne (rodzaj posiadanych aktywów i wielkość przedsiębiorstwa) okazały się współliniowe i nadmiarowe. Nie zostały one przez to uwzględnione w badanym modelu 7 .

Chociaż model 7 jest istotny statystycznie $(\mathrm{p}<\alpha)$ i spełnia założenia nałożone na 
Tabela 6. Podsumowanie wyników w ramach hipotezy 2

\begin{tabular}{|l|c|c|}
\hline \multicolumn{1}{|c|}{ Wyszczególnienie } & Wartość & p \\
\hline $\begin{array}{l}\text { Model regresji (skory- } \\
\text { gowany współczynnik } \\
\text { determinacji) }\end{array}$ & 0,34451 & 0,000247 \\
\hline $\begin{array}{l}\text { ROA (współczynnik kie- } \\
\text { runkowy) }\end{array}$ & $-0,01995$ & 0,000247 \\
\hline $\begin{array}{l}\text { Współczynnik korelacji } \\
\text { liniowej Pearsona }\end{array}$ & $-0,60469$ & 0,000247 \\
\hline
\end{tabular}

Źródło: opracowanie własne.

reszty modelu, nie potwierdza on jednak hipotezy $2 \mathrm{w}$ ramach teorii uwzględniającej koszty bankructwa. Dlatego też odrzucono hipotezę 2 , ponieważ nie została ona potwierdzona empirycznie.

Wstępne badania w ramach hipotezy 3 przeprowadzono dla próby losowej 39 spółek (model 1), przy wykorzystaniu analizy kanonicznej. W tym celu zweryfikowano założenie o rozkładzie normalnym zmiennej niezależnej (średni koszt kapitału) i zmiennych zależnych (odsetkowej tarczy podatkowej, rynkowego kursu akcji i wskaźnika zadłużenia) przez sporządzenie wykresów ich normalności oraz zastosowanie testu Shapiro-Wilka. Wykresy normalności badanych zmiennych pozwoliły na identyfikację potencjalnych punktów odstających. Zbadano również założenie o braku współliniowości przez sporządzenie macierzy korelacji liniowej Pearsona między poszczególnymi zmiennymi wewnątrz każdego zbioru danych.

Zmienne WACC, OTP i RKA nie mają rozkładu normalnego. Potwierdzają to wykresy ich normalności, w przypadku których punkty odchylają się od linii prostej, oraz test statystyczny, gdzie $\mathrm{p}<\alpha$.
Z kolei zmienna WZ posiada rozkład normalny. Potwierdza to wykres normalności, w przypadku którego punkty układają się wzdłuż linii prostej oraz test na rozkład normalny Shapiro-Wilka dla którego $\mathrm{p}>\alpha$. Nie zostało zatem spełnione dla modelu 1 założenie dotyczące rozkładu normalnego badanych zmiennych. Przyczyną braku rozkładu normalnego zmiennych moga być potencjalne punkty odstające utworzone przez następujące spółki: Boryszew, Echo, Kable, Mieszko, Mostostal-Zabrze, Prokom, Relpol, TP, Agora, Apator, Budimex, Dębica, Elzab, KGHM, Kogeneracja, Lentex, Mostostal-Warszawa, PKN Orlen, PPWK, Talex, TP, Vistula, Comarch, Kęty, Ponar, Prokom, Stalprodukt. Usunięto więc z modelu 1 dwadzieścia pięć spółek: Agora, Apator, Boryszew, Budimex, Comarch, Dębica, Echo, Elzab, Kable, Kęty, KGHM, Kogeneracja, Lentex, Mieszko, MostostalWarszawa, Mostostal-Zabrze, PKN Orlen, Ponar, PPWK, Prokom, Relpol, Stalprodukt, Talex, TP, Vistula (model 2). Dla modelu 2 składającego się z 14 spółek zbadano rozkład normalny zmiennych poprzez sporządzenie wykresów ich normalności oraz zastosowanie testu Shapiro-Wilka.

Po usunięciu punktów odstających wszystkie zmienne poddane badaniu maja rozkład normalny. Potwierdzają to wykresy normalności, w przypadku których punkty układają się wzdłuż linii prostej, oraz test na rozkład normalny Shapiro-Wilka, gdzie dla wszystkich zmiennych $\mathrm{p}>\alpha$.

W ramach drugiego zbioru współczynnik korelacji Pearsona między zmiennymi zależnymi: RKA i WZ oraz OTP i WZ są nieistotne statystycznie $z$ p $>\alpha$. Nie było zatem podstaw do ich interpretacji. Niemożliwa okazała się tym samym weryfikacja założenia o braku współliniowości między zmiennymi zależnymi w ramach drugiego

Tabela 7. Podsumowanie wyników w ramach hipotezy 3

\begin{tabular}{|l|c|}
\hline Wyszczególnienie & Pierwsza zmienna kanoniczna \\
\hline Korelacja kanoniczna & 0,34344 \\
\hline Wartość p dla zmiennej kanonicznej & 0,50144 \\
\hline Kanoniczny ładunek czynnikowy dla OTP & 0,71179 \\
\hline Kanoniczny ładunek czynnikowy dla RKA & 0,68086 \\
\hline Redundancja cząstkowa dla zbioru zmiennych zależnych & 0,05722 \\
\hline Redundancja całkowita dla zbioru zmiennych zależnych & 0,05722 \\
\hline
\end{tabular}

Źródło: opracowanie własne. 
zbioru. Obliczono dla modelu 2 zmienna i korelację kanoniczną oraz ich istotność. Korelacja kanoniczna w przypadku pierwszej (i jedynej) zmiennej kanonicznej nie jest istotna statystycznie $\mathrm{z} p>\alpha$. Nieistotność korelacji i zmiennej kanonicznej może być wynikiem występowania współliniowości w zbiorze zmiennych zależnych.

W celu eliminacji ewentualnej współliniowości $\mathrm{w}$ drugim zbiorze usunięto $\mathrm{z}$ modelu 2 poszczególne zmienne zależne: RKA (model 3), OTP (model 4), WZ (model 5) i sprawdzono nowo utworzone modele pod kątem istotności korelacji i zmiennej kanonicznej. Wybrano model charakteryzujący się najwyższą istotnością tych mierników. Najwyższą istotność (najniższą nieistotność) korelacji i zmiennej kanonicznej zaobserwowano dla modelu $5 \mathrm{z}$ jedną zmienną niezależną WACC i zbiorem zmiennych zależnych (OTP, RKA).

W celu zbadania, które zmienne (niezależne i zależne) wnoszą największy wkład do zmiennej kanonicznej obliczono dla modelu 5 wagi kanoniczne dla lewego i prawego zbioru. Do pierwszej zmiennej kanonicznej największy wkład wnoszą zmienne WACC $(-1,00)$ oraz OTP $(0,73)$. Na podstawie uzyskanych wyników otrzymano jedną parę zmiennych kanonicznych, które reprezentują w ramach modelu 5 zależność zmiennej niezależnej ze zbiorem zmiennych zależnych:

$$
\begin{gathered}
\mathrm{U}_{1}=-1,00 \mathrm{NTP} \\
\mathrm{V}_{1}=0,732734 \text { OTP }+0,702699 \text { RKA }
\end{gathered}
$$

Podsumowanie wyników analizy kanonicznej w ramach hipotezy 3 przedstawia tabela 7. Wyniki badań nie potwierdzają hipotezy 3, zgodnie z którą wzrost średniego kosztu kapitału powoduje spadek odsetkowej tarczy podatkowej, spadek rynkowego kursu akcji oraz spadek wskaźnika zadłużenia. Zmienna i korelacja kanoniczna okazały się bowiem nieistotne statystycznie, nie było zatem podstaw do ich interpretacji. Ponadto zmienna zależna WZ okazała się nadmiarowa (nie uwzględniono jej zatem w badanym modelu 5).

\section{Teoria uwzględniającej koszty agencji}

W ramach teorii uwzględniającej koszty agencji, do badań przyjęto hipotezę 4:

4. Wzrost wskaźnika stopy wypłat dywidendy, wzrost kosztów bankructwa, wzrost kosztów agencji, wzrost ryzyka działalności przedsiębiorstwa oraz wzrost unikalności produkcji powoduje spadek wskaźnika zadłużenia.

Do analizy hipotezy 4 wykorzystano wskaźniki opisujące zmienne niezależne $\mathrm{w}$ formie stopy wypłat dywidendy zdefiniowanej wzorem (3), kosztów agencji zapisanych wzorem (6), kosztów bankructwa opisanych wzorem (5), ryzyka działalności przedsiębiorstwa określonego wzorem (7), unikalności produkcji opisanej formuła (12) oraz zmienną niezależną w postaci struktury kapitałowej (wskaźnika zadłużenia), opisanego wzorem (1).

Hipotezę 4 zweryfikowano za pomocą regresji wielokrotnej i korelacji wielokrotnej (metoda właściwa dla modelu z jedną zmienną zależną i wieloma zmiennymi niezależnymi). Założono ponadto, że w przypadku, gdy spółka wygenerowała za rok obrotowy 2006 stratę netto, wskaźnik stopy wypłat dywidendy wynosi zero. Również w przypadku, gdy wskaźnik opisujący koszty agencji przyjmuje wartość ujemną, koszty agencji są zerowe. W przeciwnym razie przyjmują wyliczoną wartość dodatnią.

Wstępne badania w ramach hipotezy 4 przeprowadzono dla próby losowej 39 spółek. Sporządzono wielokrotną regresję liniową (model 1). Model regresji liniowej przybiera postać:

$$
\begin{aligned}
\mathrm{WZ} & =2,7908 \text { Ryzyko }+0,0602 \mathrm{~KB}- \\
& -0,1134 \mathrm{KA}-0,1353 \mathrm{SWD}- \\
& -0,2350 \mathrm{UP}-12,8143 .
\end{aligned}
$$

Otrzymany model regresji wyjaśnia jedynie 14,44\% zmienności WZ (skorygowany współczynnik determinacji). Wartość współczynnika determinacji na poziomie 0,2569 oznacza, że 20,69\% ogólnej zmienności WZ zostało wyjaśnione przez model. W modelu występuje jedynie jedna istotna statystycznie zmienna niezależna SWD $(p=0,032667)$. Wzrost stopy wyplat dywidendy o $1 \%$ powoduje spadek wskaźnika zadłużenia średnio o $0,1353 \%$, przy pozostałych zmiennych niezależnych pozostających na stałym poziomie. Na przedstawioną prawidłowość wskazuje również współczynnik korelacji cząstkowej Kendalla $(-0,361880)$. Ukazuje on wkład SWD do modelu $1 \mathrm{z}$ wyłączeniem oddziaływania na ten związek ryzyka działalności przedsiębiorstwa, kosztów bankructwa, kosztów agencji i unikalności produkcji. Związek 
między SWD a WZ jest umiarkowany i ujemny. Oznacza on spadek zadłużenia wraz ze wzrostem SWD. Pozostałe zmienne niezależne (ryzyko, KB, KA, UP) okazały się nieistotne statystycznie. Nie było zatem podstaw do ich interpretacji. Nieistotne okazały się również współczynniki korelacji cząstkowej dla tych zmiennych. Zatem również one nie mogły być interpretowane. Podobnie nieistotny statystycznie z $\mathrm{p}>\alpha$ był współczynnik korelacji wielokrotnej. Powyższe wskazuje, że model 1 może zawierać punkty odstające oraz nadmiarowe zmienne niezależne.

Model 1 zbadano pod kątem występowania potencjalnych punktów odstających. W tym celu sporządzono tabelę punktów odstających według przypadków oraz wykresy rozrzutu zmiennych niezależnych względem WZ. Usunięto z modelu 1 potencjalne punkty odstające:

- jedną spółkę (Mieszko) - do badania przyjęto 38 spółek (model 2 ),

- piętnaście spółek (Ampli, Apator, Groclin, Jutrzenka, KGHM, Lentex, Mieszko, Mostostal-Warszawa, Mostostal-Zabrze, Orbis, PKN Orlen, PPWK, Stalprodukt, TP, Vistula) - do badania przyjęto 24 spółki (model 3).

W badaniu pozostawiono model 1 $\mathrm{z}$ uwagi na jego najwyższy skorygowany współczynnik determinacji $(0,14437662)$ W porównaniu $\mathrm{z}$ modelem $2(0,13036006)$ i modelem $3(-0,12996845)$. Tym samym uznano, że w modelu 1 nie występują punkty odstające.

W celu stwierdzenia ewentualnej wspó1liniowości zmiennych niezależnych zbadano korelację liniową Pearsona między zmiennymi w modelu 1 . Podwyższoną, istotną $\mathrm{z} \mathrm{p}<\alpha$ korelację zaobserwowano między następującymi parami zmiennych niezależnych: ryzyko i KB $(0,326)$, ryzyko i SWD (0,383), KB i SWD (0,321). Zmienne te mogą być zatem współliniowe i nadmiarowe. Potwierdzają to wartości współczynnika determinacji między tymi zmiennymi niezależnymi a wszystkimi pozostałymi zmiennymi niezależnymi (kształtujące się na poziomie wyższym niż w przypadku UP i KA) oraz tolerancji dla tych zmiennych (kształtujące się na poziomie niższym niż wartość tego miernika dla UP i KA).

Potwierdzenie wyników w zakresie współliniowości zmiennych niezależnych stanowi podsumowanie regresji krokowej postępującej. Uzyskane wyniki wskazują, że żadna ze zmiennych niezależnych nie spełniła warunku o poziomie istotności $\alpha=0,05$. Zostały one wszystkie wyeliminowane $\mathrm{z}$ modelu regresji. Uwzględniając zatem mierniki nadmiarowości, pozostawiono w modelu jedynie zmienną niezależną UP charakteryzującą się najniższym poziomem nadmiarowości i dla tak utworzonego modelu (model 4) przeprowadzono dalszą analizę.

Model 4 jest nieistotny statystycznie $(p>\alpha)$. Również zmienna UP jest nieistotna $(p>\alpha)$, a sam model wyjaśnia zaledwie 3,75\% ogólnej zmienności zmiennej zależnej WZ (skorygowany współczynnik determinacji). Zbadano zatem istnienie w modelu 4 potencjalnych punktów odstających. Usunięto potencjalny punkt odstający (Mieszko) i sprawdzono istotność nowo utworzonego modelu 5.

Model 5 jest bardziej nieistotny w porównaniu $\mathrm{z}$ modelem 4. Ponadto pomimo że nieznacznie wzrósł skorygowany współczynnik determinacji, wzrosła również nieistotność zmiennej UP. Powrócono zatem do modelu 4. Na jego podstawie zbudowano 4 pomocnicze modele ( $\mathrm{w}$ postaci linearyzowalnej funkcji kwadratowej, wielomianowej stopnia trzeciego, potęgowej oraz wykładniczej), z których wybrany zostanie ten o maksymalnej mierze dopasowania (skorygowanym współczynniku determinacji). Diagram korelacyjny nie podpowiada bowiem jednoznacznie postaci krzywej.

$\mathrm{Z}$ uwagi na najwyższą wartość skorygowanego współczynnika determinacji $(0,073)$ do dalszych obliczeń wybrano linearyzowalną funkcję wykładniczą (model 6).

Model 6 pozostaje nadal nieistotny statystycznie, ale nieistotność ta kształtuje się na stosunkowo niskim poziomie $(\mathrm{p}=0,053)$. Zmalała również nieistotność zmiennej UP ( $\mathrm{z} \mathrm{p}=0,123866$ do poziomu 0,053045$)$ oraz wzrosła wartość skorygowanego współczynnika determinacji. W celu wykrycia w modelu 6 ewentualnych punktów odstających dokonano analizy przypadków pod postacią standaryzowanych reszt. Usunięto potencjalne punkty odstające (Apator, Lentex) i sprawdzono istotność nowo utworzonego modelu 7.

Zbadano model 7 pod kątem potencjalnych punktów odstających. Usunięto potencjalny punkt odstający (Stalprodukt) i sprawdzono istotność nowo utworzonego modelu 8. Model 8 nie posiada punktów odstających. Jest on istotny statystycznie 
$(\mathrm{p}<\alpha)$. Również zmienna UP jest istotna $(\mathrm{p}<\alpha)$, zaś udział błędu w ocenie parametru opisującego UP wynosi 30,5\% (co mieści się w akceptowalnym limicie 50\%). Model 8 wyjaśnia $21,77 \%$ ogólnej zmienności zmiennej zależnej WZ (skorygowany współczynnik determinacji). Ponieważ współczynnik kierunkowy zmiennej niezależnej UP jest ujemny $(-0,007868)$, oznacza to spadek zadłużenia wraz ze wzrostem unikalności produkcji. Prawidłowość taką potwierdza istotny, wysoki, ujemny współczynnik korelacji liniowej Pearsona między zmienną niezależną UP i zlogarytmowaną zmienną zależną WZ (-0,489978). Współczynnik korelacji rang Spearmana między tymi zmiennymi okazał się jednak nieistotny $\mathrm{z} p>\alpha$. Nie było zatem podstaw do jego interpretacji. Istotne, ujemne współczynniki regresji i korelacji liniowej Pearsona dla modelu 8 potwierdzają hipotezę 4 w części dotyczącej wpływu UP na WZ.

Model 8 jest liniowy względem parametrów. Na poziomie istotności $\alpha=0,05$ odrzucono hipotezę o nieistotności liniowego związku między zmiennymi UP i „log WZ" $(p<\alpha)$. Potwierdza to wykres rozrzutu reszt względem wartości przewidywanych, który nie sugeruje wyraźnego wzoru.

W badaniu uwzględniono próbę losową obejmującą 36 spółek, a zatem liczba obserwacji przewyższa liczbę szacowanych parametrów.

Reszty są nieskorelowane (brak jest autokorelacji). Statystyka testowa DurbinaWatsona przyjmuje wartość zbliżoną do 2 (1,966746).

Wykres rozrzutu reszt względem wartości przewidywanych wskazuje na występowanie heteroscedastyczności - reszty wzrastają bowiem względem wartości teoretycznych. Nie zachowano zatem założenia o stałości wariancji reszt, pomimo że zmienna zależna $\mathrm{WZ}$ poddana została transformacji logarytmicznej (rozpatrywany model 8 ma postać linearyzowalnej funkcji wykładniczej). W celu likwidacji heteroscedastyczności zlogarytmowano w modelu 8 również zmienną niezależną UP. Zlikwidowano tendencję wzrostową reszt, jednak kosztem istotności całego modelu regresji oraz zmiennej niezależnej „log UP”. Pozostawiono zatem model 8, z tym jednak zastrzeżeniem, że nie spełnia on założenia o stałości wariancji reszt dla wszystkich obserwacji.

Na rozkład normalny składników losowych wskazuje wykres normalności reszt. Reszty są zgodne z rozkładem normalnym. Punkty układają się bowiem wokół linii prostej (nie odchylają się od tej linii).

Przeprowadzone obliczenia wskazują, że wzrost unikalności produkcji powoduje spadek wskaźnika zadłużenia. Wyniki obliczeń potwierdzają więc (pomimo niezachowania przez rozpatrywany model 8 założenia o homoscedastyczności reszt) hipotezę 4 w części dotyczącej wpływu UP na WZ. O powyższym świadczy ujemny współczynnik kierunkowy regresji pod postacią linearyzowalnej funkcji wykładniczej, a także współczynnik korelacji liniowej Pearsona dla modelu 8 , który przyjmuje wartość ujemną $(-0,49)$ (tabela 8). Pozostałe zmienne niezależne (wskaźnik stopy wypłat dywidendy, koszty bankructwa, koszty agencji, ryzyko działalności przedsiębiorstwa) okazały się współliniowe i nadmiarowe. Nie zostały one przez to uwzględnione w badanym modelu 8 .

W związku z powyższym, pomimo że wyniki badania nie potwierdziły całej hipotezy 4, zgodnie z którą wzrost wskaźnika stopy wypłat dywidendy, wzrost kosztów bankructwa, wzrost kosztów agencji, wzrost ryzyka działalności przedsiębiorstwa oraz wzrost unikalności produkcji powoduje spadek wskaźnika zadłużenia, a sam model 8 nie spełnia jednego z założeń dotyczących analizy reszt, przyjęto jednak hipotezę $4 \mathrm{w}$ ramach teorii uwzględniającej koszty agencji w części dotyczącej wpływu unikal-

Tabela 8. Podsumowanie wyników w ramach hipotezy 4

\begin{tabular}{|l|c|c|}
\hline \multicolumn{1}{|c|}{ Wyszczególnienie } & Wartość & p \\
\hline Model regresji (skorygowany współczynnik determinacji) & $-0,21773$ & 0,00242 \\
\hline UP (współczynnik kierunkowy) & $-0,00787$ & 0,00242 \\
\hline Współczynik korelacji liniowej Pearsona & $-0,48998$ & 0,00242 \\
\hline Współczynik korelacji rang Spearmana & $-0,13411$ & 0,43553 \\
\hline
\end{tabular}

Źródło: opracowanie własne. 
ności produkcji na strukturę kapitałową. W tej części hipoteza 4 (z zastrzeżeniem dotyczącym modelu 8) została bowiem potwierdzona empirycznie.

\section{Wnioski}

Badania nie potwierdziły hipotezy 1 w ramach teorii uwzględniającej koszty bankructwa. Wykorzystany przy testowaniu hipotezy 1 model regresji wielokrotnej $\mathrm{z}$ trzema zmiennymi niezależnymi: „koszty bankructwa”, „ryzyko działalności przedsiębiorstwa”, „unikalność produkcji” był nieistotny statystycznie. Ponieważ zmienne „ryzyko działalności przedsiębiorstwa” i „unikalność produkcji” okazały się współliniowe i nadmiarowe, dalsze badania przeprowadzono dla modelu prostej regresji liniowej z jedną zmienną niezależną „koszty bankructwa”. Otrzymane wyniki (dodatni współczynnik kierunkowy prostej regresji liniowej; wysoki, dodatni współczynnik korelacji liniowej Pearsona) wskazują, że wraz ze wzrostem kosztów bankructwa wzrasta wskaźnik zadłużenia. Spółki giełdowe, zaciągając kapitał obcy, nie kierują się więc kosztami bankructwa.

Hipoteza 2 w ramach teorii uwzględniającej koszty bankructwa nie została potwierdzona empirycznie. W uwzględnionym przy testowaniu hipotezy 2 modelu regresji wielokrotnej z trzema zmiennymi niezależnymi: „wielkość przedsiębiorstwa”, „rentowność ROA”, „rodzaj posiadanych aktywów”, zmienne: „wielkość przedsiębiorstwa” i „rodzaj posiadanych aktywów” okazały się nieistotne statystycznie, współliniowe i nadmiarowe. Dalsze badania przeprowadzono zatem dla modelu prostej regresji liniowej z jedną zmienną niezależną „ROA”. Otrzymane wyniki (ujemny współczynnik kierunkowy prostej regresji liniowej; wysoki, ujemny współczynnik korelacji liniowej Pearsona oraz korelacji rang Spearmana) wskazują, że wraz ze wzrostem rentowności przedsiębiorstwa spada wskaźnik zadłużenia. Pomimo wzrostu zdolności kredytowej wskutek wzrostu rentowności, przedsiębiorstwa nie zaciągają długu. Nie wykorzystują w sposób optymalny pozytywnego efektu dźwigni finansowej.

Otrzymane wyniki nie potwierdziły hipotezy $3 \mathrm{w}$ ramach teorii uwzględniającej koszty bankructwa. Zmienna i korelacja kanoniczna okazały się nieistotne statystycznie. Nie było zatem podstaw do ich interpretacji. Ponadto zmienna zależna WZ była nadmiarowa. Tym samym niemożliwa stała się empiryczna weryfikacja

Tabela 9. Zgodność wyników testów z hipotezami

\begin{tabular}{|l|l|l|c|c|}
\hline $\begin{array}{c}\text { Nr } \\
\text { hipo- } \\
\text { tezy }\end{array}$ & $\begin{array}{c}\text { Teoria } \\
\text { struktury } \\
\text { kapitałowej }\end{array}$ & \multicolumn{1}{|c|}{ Treść hipotezy } & $\begin{array}{c}\text { Wyniki } \\
\text { testów } \\
\text { zgodne } \\
\text { z hipotezą }\end{array}$ & $\begin{array}{c}\text { Wyniki } \\
\text { testów } \\
\text { sprzeczne } \\
\text { z hipotezą }\end{array}$ \\
\hline 1 & & $\begin{array}{l}\text { Wzrost kosztów bankructwa, wzrost ryzyka } \\
\text { działalności przedsiębiorstwa oraz wzrost uni- } \\
\text { kalności produkcji wywołuje spadek wskaźnika } \\
\text { zadłużenia }\end{array}$ & $\mathrm{X}$ \\
\cline { 4 - 6 } & \multirow{2}{*}{$\begin{array}{l}\text { Uwzględniająca } \\
\text { koszty ban- } \\
\text { kructwa }\end{array}$} & $\begin{array}{l}\text { Wzrost wielkości przedsiębiorstwa, wzrost ren- } \\
\text { towności przedsiębiorstwa oraz wzrost udziału } \\
\text { rzeczowych aktywów trwałych wpływa na wzrost } \\
\text { wskaźnika zadłużenia }\end{array}$ & $\mathrm{X}$ \\
\cline { 3 - 5 } 3 & $\begin{array}{l}\text { Wzrost średniego kosztu kapitału powoduje } \\
\text { spadek odsetkowej tarczy podatkowej, spadek } \\
\text { rynkowego kursu akcji oraz spadek wskaźnika } \\
\text { zadłużenia }\end{array}$ & $\mathrm{X}$ \\
\hline 4 & $\begin{array}{l}\text { Uwzględniająca } \\
\text { koszty agencji }\end{array}$ & $\begin{array}{l}\text { Wzrost wskaźnika stopy wypłat dywidendy, } \\
\text { wzrost kosztów bankructwa, wzrost kosztów } \\
\text { agencji, wzrost ryzyka działalności przedsiębior- } \\
\text { stwa oraz wzrost unikalności produkcji skutkuje } \\
\text { spadkiem wskaźnika zadłużenia }\end{array}$ & $\begin{array}{c}\text { X } \\
\text { (czéściowo) }\end{array}$ & \\
\hline
\end{tabular}

Źródło: opracowanie własne. 
zależności między WACC, a OTP, RKA i WZ.

Przeprowadzona analiza potwierdziła częściowo hipoteze $4 \mathrm{w}$ ramach teorii uwzględniającej koszty agencji. W wykorzystanym przy testowaniu hipotezy 4 modelu regresji wielokrotnej z pięcioma zmiennymi niezależnymi: „stopa wypłaty dywidendy", „koszty bankructwa”, „koszty agencji”, „ryzyko działalności przedsiębiorstwa”, „unikalność produkcji”, zmienne: „stopa wypłaty dywidendy”, ,koszty bankructwa”, „koszty agencji”, „,ryzyko działalności przedsiębiorstwa" okazały się współliniowe i nadmiarowe. Dalsze badania przeprowadzono zatem dla modelu prostej regresji liniowej z jedną zmienną niezależną ,unikalność produkcji”. Chociaż model ten nie spełnia założenia o homoscedastyczności reszt, jest on istotny statystycznie. Istotna jest również zmienna „unikalność produkcji”. Otrzymane wyniki (ujemny współczynnik kierunkowy prostej regresji liniowej; wysoki, ujemny współczynnik korelacji liniowej Pearsona) wskazują, że wraz ze wzrostem unikalności produkcji spada wskaźnik zadłużenia. Wskazuje to, że im bardziej unikalny jest wyrób, tym zadłużenie przedsiębiorstw produkujących takie wyroby spada.

W tabeli 9 porównano wyniki przeprowadzonych testów $\mathrm{z}$ hipotezami.

\section{Bibliografia}

Aczel, A.D. (2005). Statystyka w zarzadzaniu. Warszawa: Wydawnictwo Naukowe PWN.

Agrawal, A. i Knoeber, Ch.R. (1996). Firm Performance and Mechanisms to Control Agency Problems Between Managers and Shareholders. Journal of Financial and Quantitative Analysis, 31(3).

Agrawal, A. i Nagarajan, N.J. (1990). Corporate Capital Structure, Agency Costs, and Ownership Control: The Case of All-Equity Firms. Journal of Finance, 45(4).

Akhtar, S. (2005). The Determinants of Capital Structure for Australian Multinational and Domestic Corporations. Australian Journal of Management, $30(2)$.

Allen, D.E., Mizuno, H. (1989). The Determinants of Corporate Capital Structures: Japanese Evidence. Applied Economics, 21(5).

Ang, J.S., Cole, R.A. i Lin, J.W. (2000). Agency Costs and Ownership Structure. Journal of Finance, 55(1).

Bancel, F. i Mittoo, U.R. (2004). Cross-Country Determinants of Capital Structure Choice: A Sur- vey of European Firms. Financial Management, 33(4).

Baxter, N.D. (1967). Leverage, Risk of Ruin and the Cost of Capital. Journal of Finance, 22(3).

Berger, P.G., Ofek, E. i Yermack, D.L. (1997). Managerial Entrenchment and Capital Structure Decisions. Journal of Finance, 52(4).

Bhaduri, S.N. (2002). Determinants of capital structure choice: a study of the Indian corporate sector. Applied Financial Economics, 12(9).

Booth, L., Aivazian, V., Demirguc-Kunt, A. i Maksimovic, V. (2001). Capital Structures in Developing Countries. Journal of Finance, 56(1).

Cassar, G. i Holmes, S. (2003). Capital Structure and Financing of SMEs: Australian Evidence. Accounting and Finance, 43(2).

Chang, Ch. (1992). Capital Structure as an Optimal Contract Between Employees and Investors. Journal of Finance, 47(3).

Colombo, E. (2001). Determinants of corporate capital structure: evidence from Hungarian firms. Applied Economics, 33(13).

Datta, S., Iskander-Datta, M. i Raman K. (2005). Managerial Stock Ownership and the Maturity Structure of Corporate Debt. Journal of Finance, 60(5).

Dittmar, A. i Thakor, A. (2007). Why Do Firms Issue Equity. Journal of Finance, 62(1).

Fosberg, R.H. (2004). Agency Problems and Debt Financing: Leadership Structure Effects. Corporate Governance, 4(1).

Frielinghaus, A., Mostert, B. i Firer, C. (2005). Capital structure and the firm's life stage. South African Journal of Business Management, 36(4).

Friend, I. i Lang, L.H. (1988). An Empirical Test of The Impact of Managerial Self-Interest, Journal of Finance, 43(2).

Gajdka, J. (2002). Teorie struktury kapitatu i ich aplikacja w warunkach polskich. Łódź: Wydawnictwo Uniwersytetu Łódzkiego.

Harris, M. i Raviv, A. (1990). Capital Structure and the Informational Role of Debt. Journal of Finance, 45(2).

Harris, M. i Raviv, A. (1991). The Theory of Capital Structure. Journal of Finance, 46(1).

Harvey, C.R, Lins, K.V. i Roper, A.H. (2004). The effect of capital structure when expected agency costs are extreme. Journal of Financial Economics, 74(1).

Haugen, R.A. i Senbet L.W. (1978). The insignificance of bankruptcy costs to the theory of optimal capital structure. Journal of Finance, 33(2).

Heinkel, R. (1982). A Theory of Capital Structure Relevance under Imperfect Information Journal of Finance, 37(5). 
Hovakimian, A., Opler, T. i Titman, S. (2001). The Debt-Equity Choice. Journal of Financial and Quantitative Analysis, 36(1).

Jerzemowska, M. (1999). Ksztattowanie struktury kapitału $w$ spótkach akcyjnych. Warszawa: Wydawnictwo Naukowe PWN.

Kim, E.H. (1978). A Mean-Variance Theory of Optimal Capital Structure and Corporate Debt Capacity. Journal of Finance, 33(1).

Kraus, A. i Litzenberger R.H. (1973). A StatePreference Model of Optimal Financial Leverage. Journal of Finance, 28(4).

Leland, H.E. (1998). Agency Costs, Risk Management and Capital Structure. Journal of Finance, 53(4).

Leland, H.E. i Toft, K.B. (1996). Optimal Capital Structure, Endogenous Bankruptcy and the Term Structure of Credit Spreads. Journal of Finance, 51(3).

Maksimovic, V. i Zechner J. (1991). Debt, Agency Costs, and Industry Equilibrium. Journal of Finance, 46(5).

Mehran, H. (1992). Executive Incentive Plans, Corporate Control and Capital Structure. Journal of Financial and Quantitative Analysis, 27(4).

Miao, J. (2005). Optimal Capital Structure and Industry Dynamics. Journal of Finance, 60(6).

Miller, M.H. (1977). Debt and Taxes. Journal of Finance, 32(2).

Myers, S.C. (1984). The Capital Structure Puzzle. Journal of Finance, 39(3).

Mynarski S. (2000). Praktyczne metody analizy danych rynkowych i marketingowych. Kraków: Zakamycze.

Opler, T.C. i Titman, S. (1994). Financial Distress and Corporate Performance. Journal of Finance, 49(3).
Ozkan, A. (2001). Determinants of capital structure and adjustment to long run target: Evidence from UK company panel data. Journal of Business Finance \& Accounting, 28(1-2).

Panno, A. (2003) An empirical investigation on the determinants of capital structure: the UK and Italian experience. Applied Financial Economics, 13(2).

Rajan, R.G. i Zingales, L. (1995). What do we know about capital structure: Some evidence from international data. Journal of Finance, 50(5).

Ross, S.A., Westerfield, R.W. i Jaffe, J.F. (1990). Corporate Finance. Boston: Irwin Homewood.

Ross, S.A., Westerfield, R.W., Jordan, B.D. (1993). Fundamentals of Corporate Finance. Boston: Irwin Homewood.

Stanisz, A. (2001). Przystępny kurs statystyki w oparсіи о programu STATISTICA PL na przyktadach $z$ medycyny. Kraków: Statsoft.

Stiglitz, J.E. (1988). Why Financial Structure Matters. Journal of Economic Perspectives, 2(4).

Titman, S., Tompaidis, S. i Tsyplakov S. (2004). Market Imperfections, Investment Flexibility and Default Spreads. Journal of Finance, 59(1).

Titman, S. i Wessels, R. (1988). The Determinants of Capital Structure Choice. Journal of Finance, 43(1).

Voulgaris, F., Asteriou, D. i Agiomirgianakis, G. (2004). Size and Determinants of Capital Structure in the Greek Manufacturing Sector. International Review of Applied Economics, 18(2).

Wald, J.K. (1999). How Firm Characteristics Affect Capital Structure: An International Comparison. Journal of Financial Research, 22(2).

Warner, J.B. (1977). Bankruptcy Costs: Some Evidence. Journal of Finance, 32(2). 